IZA DP No. 4236

Long-Term Impact of Youth Minimum Wages:

Evidence from Two Decades of Individual Longitudinal Data

Ana Rute Cardoso

June 2009 


\title{
Long-Term Impact of Youth Minimum Wages: Evidence from Two Decades of Individual Longitudinal Data
}

\author{
Ana Rute Cardoso \\ IAE Barcelona (CSIC) \\ and IZA
}
Discussion Paper No. 4236
June 2009

IZA

P.O. Box 7240

53072 Bonn

Germany

\author{
Phone: +49-228-3894-0 \\ Fax: +49-228-3894-180 \\ E-mail: iza@iza.org
}

\begin{abstract}
Any opinions expressed here are those of the author(s) and not those of IZA. Research published in this series may include views on policy, but the institute itself takes no institutional policy positions.

The Institute for the Study of Labor (IZA) in Bonn is a local and virtual international research center and a place of communication between science, politics and business. IZA is an independent nonprofit organization supported by Deutsche Post Foundation. The center is associated with the University of Bonn and offers a stimulating research environment through its international network, workshops and conferences, data service, project support, research visits and doctoral program. IZA engages in (i) original and internationally competitive research in all fields of labor economics, (ii) development of policy concepts, and (iii) dissemination of research results and concepts to the interested public.
\end{abstract}

IZA Discussion Papers often represent preliminary work and are circulated to encourage discussion. Citation of such a paper should account for its provisional character. A revised version may be available directly from the author. 


\begin{abstract}
Long-Term Impact of Youth Minimum Wages: Evidence from Two Decades of Individual Longitudinal Data

This paper quantifies the long-run impact of exposure to youth minimum wages and sheds light on its mechanisms. It uses remarkable longitudinal data spanning for twenty years and explores legislative changes that define groups of teenagers exposed for different durations. After controlling for the contemporaneous impact of the minimum wage, its long-run impact translates into: an overall wage premium, consistent with an upgrading in the quality of jobs offered; a flatter tenure-earnings profile, consistent with lower initial investment in firmspecific training. Interestingly, the overall wage premium increases with exposure and the tenure-earnings profile is flatter the longer the exposure.
\end{abstract}

JEL Classification: J08, J31, J24, J38

Keywords: skill formation, human capital investment, on-the-job-training, career, long-term, linked employer-employee data

Corresponding author:

Ana Rute Cardoso

IAE-CSIC

Campus UAB

08193 Bellaterra

Barcelona

Spain

E-mail: anarute.cardoso@iae.csic.es

\footnotetext{
* I am grateful to João Cerejeira and Dan Hamermesh for helpful comments and to the Ministry of Employment, Statistics Department, for access to the data used. I acknowledge the support of the Barcelona GSE Research Network, the Government of Catalonia, and the Portuguese Science Foundation under project grant PTDC/ECO/74047/2006.
} 


\section{Introduction}

Little is known about the impact of exposure to minimum wages at young ages on long-term labor market outcomes and contradictory hypotheses have been put forth. On one hand, human capital theory predicts that firms will reduce investment in training after an increase in the minimum wage, since it prevents workers from taking wage cuts necessary to fund training. Also, school enrollment could decline, as teenagers would drop out of school to start working. On the contrary, the minimum wage legislation could lead employers into offering better quality jobs and workers could increase their investment in skill acquisition, if that were perceived as a requirement to access jobs. Additionally, if minimum wages increase the likelihood of unemployment, they will worsen career prospects for the affected workers, whereas if they raise job attachment and increase employment, they will contribute to improve longer-term career outcomes. The empirical literature testing the long-term impact of minimum wages is restricted to Neumark and Nizalova (2007), who have conducted their analysis at a very aggregate level (cells defined by state-year-age) and computed exposure to minimum wages as the average minimum wage to which individuals in each cell would have been entitled at earlier ages, if they had been in the labor market in the state of current residence. Also, they have not attempted to shed light on the mechanisms that may drive the impact of minimum wages, focusing only on the quantification of the overall impact.

The first aim of this paper is therefore to quantify the impact of exposure to high youth minimum wages on long-term outcomes, using a dataset that tracks the worker's actual employment and wage history since early ages, spanning for almost two decades with coverage of the population of workers and firms in the private sector of a European Union economy, Portugal. The first question to be addressed is: How does exposure to high minimum wages at young ages affect long-term worker's wages?

In the vein of Neumark and Nizalova (2007), potential exposure to minimum wages will first be considered, by taking into account just the worker's age at different points in time and the level of the minimum wage that was then enforced, disregarding at an initial stage of the analysis whether the worker was actually already in the labor market or not. 
The subsequent steps extend the analysis into several dimensions. In the next step, actual exposure to minimum wages is distinguished from potential exposure. Instead of simply reflecting eligibility to earn the minimum wage, actual exposure takes into account the worker's age and time of entry into the labor market; as such, exposure to a particular level of the minimum wage is considered to have taken place only if the individual had already joined the labor market. Still in the vein of Neumark and Nizalova, up to this point the analysis does not explore the mechanisms that may drive the impact of the minimum wage, as it does not control for productivity-related variables. In particular, the role played by education is absent from the picture, so as to capture the full impact of the minimum wage, whichever channel of operation.

The second aim of the analysis is precisely to shed some light on the mechanisms through which the minimum wage may operate. Two specific hypotheses will be tested: i) according to human capital theory, as stated in particular by Becker (1993, first published 1964) and Hashimoto (1982), firms will reduce on-the-job training following an increase in the minimum wage, with a negative impact on the worker's human capital accumulation and future wage profile; ii) on the contrary, according to more recent theories that allow for labor market imperfections, such as that developed by Acemoglu and Pischke (1999), firms will increase the provision of on-the-job general training following an increase in the minimum wage. I hypothesize that this will lead to an overall wage premium, comparable to an upgrading in the quality of jobs offered. The tests will be performed while controlling for another potential mechanism of operation of youth minimum wages: its impact on schooling.

To accomplish these aims, I rely on two sets of remarkable conditions. First of all, I exploit a sharp change in the legislation that took place in mid-80's, which raised minimum wages by $50 \%$ for some youth age levels and by $33 \%$ for other youth age levels, enabling a clear definition of groups of workers who have been exposed to high minimum wages at different ages and for different durations. Part of these legislative changes have been analyzed in a different setting, i.e. to check the short-run employment impact of minimum wages (Pereira, 2003) and its impact on worker flows and firms' recruitment and dismissal policies (Portugal and Cardoso, 2006). 
Secondly, I rely on a longitudinal matched employer-employee dataset of unusual quality, which follows from 1987 to 2005 the population of firms with wageearners in the private sector, as well as the population of its workers. Therefore, problems commonly faced by panel datasets, such as panel attrition and over- or under-sampling of certain groups, are avoided. Moreover, the legal requirement for the data to be posted in a public space inside the firm contributes to its reliability, reducing measurement errors.

Section 2 explores the mechanisms that may lead youth minimum wages to have a long-term impact on wages. Section 3 clarifies the institutional setting and section 4 describes the data. Section 5 provides evidence on teenage wage trends under changing minimum wages, highlighting the remarkable impact that the legislative changes had on the wage distribution. Section 6 describes the empirical model and discusses its results. Concluding comments are presented in section 7.

\section{Why would exposure to high youth minimum wages im- pact long-term wages?}

Three mechanisms that influence human capital accumulation have been pointed out in the literature as triggering an impact of youth minimum wages on workers' long-term wage profiles: on the-job-training, schooling, and the employment / unemployment channel. This section clarifies how each of these mechanisms is considered in the current analysis.

Becker's analysis of human capital formation provides the framework on the impact of on-the-job training on wages in competitive markets (Becker, 1993: 30-51, first published 1964) and Hashimoto (1982) extended this type of setting to explicitly handle the influence of youth minimum wages on long-term wages. Under the human capital general setting, on-the-job training raises the future earnings capacity of the worker, while being subject to a current cost, associated with the materials consumed, equipment used, instructors' time and the trainees opportunity cost of time spent in training (foregone production). Since the worker reaps the benefits of training in the form of higher future earnings, the firm has no incentive to provide training, unless it can make the worker bear its cost, in the form of a lower current wage. In general, a profit-maximizing firm will therefore make the worker fully pay for general training (which results in skills that are val- 
ued throughout the labor market), while it will accept to pay for part of the cost of firm-specific training (which results in skills that are of value only to the firm concerned). The current wage of a trainee would therefore equal his/her potential productivity, deducted of the cost of training. A clear prediction follows: wage growth should be faster for workers who receive on-the-job training, compared to those who do not.

Similarly, in Hashimoto's (1982) model the worker's current wage equals the value of the worker's marginal productivity net of the cost of training. An increase in the amount of training offered could take place at the expense of a lower current wage, in a compensating differentials type of argument, since both monetary returns and training would be part of the compensation package; conversely, for the same level of training, an increase in wage mandated by the legislation would lead to a reduction in the quantity of labor demanded by the firm (while leading to an increase in the quantity of labor supplied). Job competition would, as a result, put downward pressure on the training provided, thus increasing demand and reducing supply of labor. A new equilibrium would be established, with lower on-the-job training. ${ }^{1}$ The general setting of human capital theory therefore predicts that firms will reduce investment in on-the-job training after an increase in the minimum wage, since it prevents workers from taking wage cuts necessary to fund training.

A different set of models allow for market imperfections, in which case the role of general training is crucial. Acemoglu and Pischke (1999) explicitly consider labor market frictions that compress the distribution of wages relative to the distribution of productivities. Such frictions include collective bargaining wage floors, national minimum wages, asymmetric information between current and prospective employer, or job search and other mobility costs. Under any of these mechanisms, the outside wage option of an employed worker is lower than her productivity. ${ }^{2}$ For example, the worker may have to incur a mobility cost, such that, even if she were paid her marginal product in the new firm, the net benefit would be lower; the possibility of an intervening period of unemployment also lowers the net benefit from job changing; prospective employers cannot fully observe the worker's skill (even if it results from general training) and therefore the wage offer may not fully

\footnotetext{
${ }^{1}$ And an ambiguous effect on the level of employment, which would depend on the change in training costs as the amount of training declines.

${ }^{2}$ Which is common across firms, given that all training is general.
} 
reflect it. Any of these frictions gives the current employer some monopsony power, i.e. the ability to pay the worker a wage below her marginal productivity, as it takes into account the worker outside option. ${ }^{3}$ Moreover, most of these frictions mean that the rents the firm extracts from skilled workers are larger than those it extracts from the unskilled - if the cost of unemployment is larger for the skilled, in particular when the unemployment benefit system is progressive; when higher skills are harder to observe by prospective employers; or when minimum wages are enforced. Therefore, training will raise the productivity of the worker more than it raises her wage and this power to extract rents from the worker, in particular from skilled workers, drives the firm willingness to invest in general skills. Stated intuitively, if the firm provides training the worker's productivity will increase but, given the compression of the wage distribution, the firm does not have to fully pay the worker for the productivity improvement. Since it keeps some of the surplus, even when wages increase the firm is willing to keep the worker and it will increase investment in general human capital, so as to increase the level of surplus it obtains. "[A]s the wage structure becomes more compressed, firms pay for a larger fraction of the costs of general training, and when the structure of wages is sufficiently distorted, they may pay for all the costs." (Acemoglu and Pischke, 1999: 541) In other words, firms would upgrade the general skills of its workers and the type of jobs they offer.

Stevens (1994) makes a related claim that, depending on the market structure where wages are determined, firms can appropriate a part of the returns to training and will as such have an interest in investing in the worker's human capital. Moreover, according to her model, training itself may have an impact reducing competition, as it can increase differentiation among firms and among workers. Manning (2003) provides a thorough discussion of the provision of firm general and specific training in labor markets with frictions, showing that in general firms will be willing to provide and pay for training. Booth and Zoega (2004) call attention to the fact that the wage compression required for the result by Acemoglu and Pischke to hold occurs in situations that are much more general than the common interpretation of the authors' terminology "wage compression" would lead us to think. They underline that firms would be willing to invest in the general human capital of the worker even in settings such as piece-rate payment, usually

\footnotetext{
${ }^{3}$ Assuming the firm has some bargaining power.
} 
associated with competitive wages and no market distortions.

This reasoning of "upgrading the quality of jobs" or "high wage strategy" is often implicit in the aims of policy makers, when claiming that minimum wages will raise the living standards of the low paid while contributing to develop general skills.

Two testable implications therefore follow from human capital models and more recent models of labor market imperfections. First of all, if the minimum wage reduces the provision of firm-specific training, the tenure-earnings profile would be flatter for workers exposed to youth minimum wages. These lower returns to seniority within the firm would be a direct consequence of the lower amount of human capital specific to the firm embodied in the worker. Secondly, if the minimum wage raises investment in general training, with firms adopting more of a job upgrading strategy, we should observe a positive impact of exposure to youth minimum wages, which could take the form of an overall wage premium for exposed workers or a steeper experience-earnings profile. This study aims at testing these two hypotheses.

Empirically, the impact of minimum wages on on-the-job training has been tested by using either direct information on training undertaken by the worker or indirect evidence on wage progression for short periods of one to three years, yielding mixed results (for recent evidence using information on training, see Neumark and Wascher (2001), Fairris and Pedace (2004) and Arulampalam et al (2004), and for studies based on wage growth see Hashimoto (1982), Grossberg and Sicilian (1999), Acemoglu and Pischke (2003) and Simpson (1984)).

The second mechanism linking minimum wages to human capital formation is investment in formal schooling. Workers may increase their investment in schooling, so as to raise their productivity and compete for jobs (Cahuc and Michel, 1996), to avoid employment in a secondary sector where no minimum wage is enforced (Agell and Lommerud, 1997), or to compensate for the decline in wages due to the reduction of on-the-job training (Ravn and Sorensen, 1999). ${ }^{4}$ The empirical specifications in the current work will control for the impact of schooling on wages when testing for the long-term impact of minimum wages, remaining agnostic as to the impact of the minimum wage on schooling. Given the general trend in the

\footnotetext{
${ }^{4}$ The empirical results on this are mixed (see Ehrenberg and Marcus (1982), Campolieti et al (2005), Turner and Demiralp (2001), Neumark and Wascher $(1995,1996)$ and Hyslop and Stillman (2007)).
} 
economy towards an increase in the level of schooling, younger cohorts (precisely those more affected by high youth minimum wages) have higher schooling levels and no causal link can be established on whether that was partly driven by the minimum wage or, on the contrary, in its absence, the increase in the schooling level of younger cohorts would have been even more pronounced.

One third mechanism could operate to influence the wage profile of workers affected by minimum wages when young: the employment channel. I rely on Portugal and Cardoso's (2006) results, who found that in the specific setting of the country under analysis and these legislative changes, the minimum wage did not have a detrimental impact on employment, due to the increased job attachment it generated on youth already in employment, which compensated for the negative demand side impact predicted by human capital theory. For this reason I avoid exploring again here the impact of minimum wages on employment.

\section{Institutional setting: minimum wage, compulsory edu- cation and working age}

A mandatory national minimum wage was introduced in Portugal in 1974, covering workers aged 20 or older and excluding agriculture and household services. Ever since, it has been annually updated by the parliament, under government proposal..$^{5}$ Decisions on the level of the minimum wage are taken on a discretionary basis, usually taking into account past and predicted inflation and a consultation with employers and workers representatives. It is defined as monthly earnings and each year any mandated changes take effect in January.

Since it was first enacted, the minimum wage has undergone several changes concerning its age coverage, summarized in table 1.

\begin{tabular}{r|c|c|c|c|c|c|c}
\hline & \multicolumn{7}{|c}{ Age Group } \\
\cline { 2 - 8 } Year & 14 & 15 & 16 & 17 & 18 & 19 & 20 or older \\
\hline 1979 to 1986 & 50 & 50 & 50 & 50 & 75 & 75 & 100 \\
1987 & 50 & 50 & 50 & $\mathbf{7 5}$ & $\mathbf{1 0 0}$ & $\mathbf{1 0 0}$ & 100 \\
1988 & $\mathbf{7 5}$ & $\mathbf{7 5}$ & $\mathbf{7 5}$ & 75 & 100 & 100 & 100 \\
\hline
\end{tabular}

Table 1: Share of the general minimum Wage Enforced, ACCORding to the Age of THE WORKER (\%) Source: Portugal, Diário da República, several issues.

Three changes in the legislation are worth highlighting:

\footnotetext{
${ }^{5}$ The only exceptions were 1982, when it was not updated, and 1989, when it was updated twice.
} 
- in 1987 the minimum wage for workers aged 17 increased by 50 percent due to changes in the legislation ceteris paribus, as it was raised from half to 75 percent of the full minimum wage;

- also in 1987, the minimum wage for workers aged 18 or 19 was raised from 75 percent of the minimum wage to the full minimum, therefore increasing by 33 percent;

- in 1988, the minimum wage for workers aged 14 to 16 was raised from 50 percent to 75 percent of the full minimum, thus increasing by 50 percent.

Following these legislative changes, different groups of teenagers were potentially exposed to a high youth minimum wage at different ages and for different durations. It is particularly enlightening to consider the worker age as of 1987: individuals then aged 20 or older were never exposed to high youth minimum wages, while those aged 14 (and therefore old enough to work under the legislation enforced at the time), were eligible to five years of high youth minimum wages, with the whole range of potential exposure for ages in-between. Table 2 makes this point more explicit.

\begin{tabular}{c|c|c|c|c|c|c|c|c|c||c}
\hline year & 1987 & 1988 & 1989 & 1990 & 1991 & 1992 & 1993 & $\ldots$ & 2005 & $\begin{array}{c}\text { potent. expos. } \\
\text { to high youth } \\
\text { min w (years) }\end{array}$ \\
\hline \hline age & 14 & $\mathbf{1 5}$ & $\mathbf{1 6}$ & $\mathbf{1 7}$ & $\mathbf{1 8}$ & $\mathbf{1 9}$ & 20 & $\ldots$ & 32 & 5 \\
(in bold & 15 & $\mathbf{1 6}$ & $\mathbf{1 7}$ & $\mathbf{1 8}$ & $\mathbf{1 9}$ & 20 & 21 & $\ldots$ & 33 & 4 \\
if eligible & 16 & $\mathbf{1 7}$ & $\mathbf{1 8}$ & $\mathbf{1 9}$ & 20 & 21 & 22 & $\ldots$ & 34 & 3 \\
to high & $\mathbf{1 7}$ & $\mathbf{1 8}$ & $\mathbf{1 9}$ & 20 & 21 & 22 & 23 & $\ldots$ & 35 & 3 \\
youth & $\mathbf{1 8}$ & $\mathbf{1 9}$ & 20 & 21 & 22 & 23 & 24 & $\ldots$ & 36 & 2 \\
minimum & $\mathbf{1 9}$ & 20 & 21 & 22 & 23 & 24 & 25 & $\ldots$ & 37 & 1 \\
wage) & 20 & 21 & 22 & 23 & 24 & 25 & 26 & $\ldots$ & 38 & 0 \\
\hline
\end{tabular}

Table 2: Eligibility (Potential exposure) TO High youth Minimum WageS

Actual exposure to high youth minimum wages, however, must take into account the year the worker joined the labor market and his/her age at the time. Table 3 clarifies the number of years of actual exposure to high youth minimum wages, based on age and year of entry into the labor market.

Compulsory education used to be in Portugal 6 years, until it was set at 9 years for students entering in 1987 their first year of primary education. ${ }^{6}$ In other words, by 1996 the compulsory schooling level was raised to 9 years, and the age at which

\footnotetext{
${ }^{6}$ Law $46 / 86$.
} 


\begin{tabular}{c|c||c|c|c|c|c|c|c}
\hline $\begin{array}{c}\text { year of entry } \\
\text { into lab. market }\end{array}$ & $\begin{array}{c}1987 \\
\text { or earlier }\end{array}$ & 1988 & 1989 & 1990 & 1991 & 1992 & $\begin{array}{c}1993 \\
\text { or later }\end{array}$ \\
\hline \hline age, & 14 & 5 & 5 & 4 & 3 & 2 & 1 & 0 \\
as of & 15 & 4 & 4 & 3 & 2 & 1 & 0 & 0 \\
March 1987 & 16 & 3 & 3 & 2 & 1 & 0 & 0 & 0 \\
& 17 & 3 & 2 & 1 & 0 & 0 & 0 & 0 \\
& 18 & 2 & 1 & 0 & 0 & 0 & 0 & 0 \\
& 19 & 1 & 0 & 0 & 0 & 0 & 0 & 0 \\
& 20 & 0 & 0 & 0 & 0 & 0 & 0 & 0 \\
\hline
\end{tabular}

Table 3: Number of YeARs of ACTUAL EXPOSURE TO HIGH YOUTH Minimum WAGES. Note: The reference month of March was chosen simply because it was the reference month for data collection.

compulsory education finishes set at 15 years old.

Until 1992 the legal minimum age to work was 14 years old ${ }^{7}$; as of January 1992 it was raised to 15 years and from January 1997 onwards it was raised to 16 years $^{8}$, in accordance with the legislation that set compulsory education at 9 years of schooling and until the age of 15 . Individuals aged 15 who have completed compulsory education can perform "light work", whereas those aged 15 who have not yet completed compulsory education can only perform work related to training that will not jeopardize completion of compulsory education.

\section{Dataset and definition of concepts}

The analysis relies on administrative longitudinal data on workers and their firms (Quadros de Pessoal), gathered annually by the Ministry of Employment in an inquiry that every firm with wage earners is legally obliged to fill in. Information on all the personnel working for the firm in a reference week (in March until 1993 and in October since 1994) is reported. The personnel on short leave (such as sickness, maternity, strike or holidays) is included, whereas personnel on longterm leave (such as military service) is not reported. Public administration and domestic service are not covered and the coverage of agriculture is low, given its low share of wage earners. For the remaining sectors, the mandatory nature of the survey leads to an extremely high response rate, and in practice the population of wage earners in manufacturing and the services private sector is covered. Reported data on the worker include gender, age, schooling, occupation, seniority within the firm, monthly earnings (split into several components), and duration of work. ${ }^{9}$ The

\footnotetext{
${ }^{7}$ Decree-law 49.408 of 1969.

${ }^{8}$ Decree-law 396/91 and law 46/86.

${ }^{9}$ The database also includes information on the employer, such as the industry, location, size, gross revenue, and origin of capital (private national, foreign, or public).
} 
data cover a long period of almost twenty years and information from 1987 to 2005 are used..$^{10}$

A worker identification code, based on a transformation of the social security number, enables tracking him/her over time. Extensive checks have been performed to guarantee the accuracy of the longitudinal data, using the variables gender, date of birth, highest schooling level achieved, and worker identification code (see appendix A for further details).

For this study, workers aged 14 to 20 years as of March 1987 are tracked over the whole period 1987 to $2005 .{ }^{11}$ Note that all workers ever observed in the data set who fulfill that requirement are kept for analysis, irrespective of whether they were actually observed working in 1987, therefore capturing the whole cohort. By 2005, the latest year under analysis, these workers were aged 32 to 38 years. ${ }^{12}$ This resulted in 6,368,256 observations on 1,134,356 workers. Table 4 shows the size of this population, by year and observed age.

\footnotetext{
${ }^{10}$ No worker data is available for 1990 and 2001.

${ }^{11}$ The March cutoff month was chosen simply because it was the reference month for the data collection until 1993.

${ }^{12}$ Given that the reference month changed from March to October, a share of the workers will by 2005 be 39 years old.
} 


\begin{tabular}{|c|c|c|c|c|c|c|c|c|c|c|c|c|c|c|c|c|c|}
\hline $\begin{array}{l}\text { obs. } \\
\text { age }\end{array}$ & $\begin{array}{r}\text { March } \\
1987\end{array}$ & $\begin{array}{r}\text { March } \\
1988\end{array}$ & $\begin{array}{r}\text { March } \\
1989\end{array}$ & $\begin{array}{r}\text { March } \\
1991\end{array}$ & $\begin{array}{r}\text { March } \\
1992\end{array}$ & $\begin{array}{r}\text { March } \\
1993\end{array}$ & $\begin{array}{r}\text { Oct } \\
1994\end{array}$ & $\begin{array}{r}\text { Oct } \\
1995\end{array}$ & $\begin{array}{r}\text { Oct } \\
1996\end{array}$ & $\begin{array}{r}\text { Oct } \\
1997\end{array}$ & $\begin{array}{r}\text { Oct } \\
1998\end{array}$ & $\begin{array}{r}\text { Oct } \\
1999\end{array}$ & $\begin{array}{r}\text { Oct } \\
2000\end{array}$ & $\begin{array}{r}\text { Oct } \\
2001\end{array}$ & $\begin{array}{r}\text { Oct } \\
2003\end{array}$ & $\begin{array}{r}\text { Oct } \\
2004\end{array}$ & $\begin{array}{r}\text { Oct } \\
2005\end{array}$ \\
\hline 14 & 1,009 & & 0 & 0 & 0 & 0 & 0 & 0 & 0 & 0 & 0 & 0 & 0 & 0 & 0 & 0 & 0 \\
\hline 15 & 5,281 & 6,227 & 0 & 0 & 0 & 0 & 0 & 0 & 0 & 0 & 0 & 0 & 0 & 0 & 0 & 0 & 0 \\
\hline 16 & 10,154 & 11,838 & 14,402 & 0 & 0 & 0 & 0 & 0 & 0 & 0 & 0 & 0 & 0 & 0 & 0 & 0 & 0 \\
\hline 17 & 15,469 & 16,979 & 20,422 & 0 & 0 & 0 & 0 & 0 & 0 & 0 & 0 & 0 & 0 & 0 & 0 & 0 & 0 \\
\hline 18 & 20,834 & 22,146 & 25,277 & 29,143 & 0 & 0 & 0 & 0 & 0 & 0 & 0 & 0 & 0 & 0 & 0 & 0 & 0 \\
\hline 19 & 25,911 & 26,965 & 30,228 & 34,213 & 35,873 & 0 & 0 & 0 & 0 & 0 & 0 & 0 & 0 & 0 & 0 & 0 & 0 \\
\hline 20 & 28,560 & 29,683 & 32,854 & 37,513 & 39,280 & 38,714 & 0 & 0 & 0 & 0 & 0 & 0 & 0 & 0 & 0 & 0 & 0 \\
\hline 21 & 0 & 30,602 & 33,399 & 37,568 & 39,328 & 40,598 & 18,524 & 0 & 0 & 0 & 0 & 0 & 0 & 0 & 0 & 0 & 0 \\
\hline 22 & 0 & 0 & 39,378 & 42,326 & 44,518 & 44,369 & 46,821 & 20,709 & 0 & 0 & 0 & 0 & 0 & 0 & 0 & 0 & 0 \\
\hline 23 & 0 & 0 & 0 & 47,516 & 48,689 & 48,102 & 50,255 & 51,681 & 21,995 & 0 & 0 & 0 & 0 & 0 & 0 & 0 & 0 \\
\hline 24 & 0 & 0 & 0 & 50,029 & 51,592 & 50,507 & 50,483 & 54,750 & 54,676 & 24,760 & 0 & 0 & 0 & 0 & 0 & 0 & 0 \\
\hline 25 & 0 & 0 & 0 & 0 & 53,407 & 52,439 & 53,443 & 54,443 & 56,853 & 60,966 & 26,331 & 0 & 0 & 0 & 0 & 0 & 0 \\
\hline 26 & 0 & 0 & 0 & 0 & 0 & 53,793 & 55,115 & 56,611 & 55,470 & 62,081 & 64,226 & 28,707 & 0 & 0 & 0 & 0 & 0 \\
\hline 27 & 0 & 0 & 0 & 0 & 0 & 0 & 56,083 & 57,329 & 57,053 & 59,747 & 64,663 & 68,783 & 30,117 & 0 & 0 & 0 & 0 \\
\hline 28 & 0 & 0 & 0 & 0 & 0 & 0 & 32,784 & 57,679 & 57,407 & 60,613 & 61,423 & 68,756 & 71,743 & 0 & 0 & 0 & 0 \\
\hline 29 & 0 & 0 & 0 & 0 & 0 & 0 & 0 & 33.677 & 57,492 & 60,151 & 61.621 & 64,554 & 71.589 & 32.257 & 0 & 0 & 0 \\
\hline 30 & 0 & 0 & 0 & 0 & 0 & 0 & 0 & 0 & 33,597 & 60,050 & 61,282 & 64,488 & 66,832 & 76,576 & 32,966 & 0 & 0 \\
\hline 31 & 0 & 0 & 0 & 0 & 0 & 0 & 0 & 0 & 0 & 34,718 & 60,440 & 63,863 & 66,418 & 75,612 & 77,657 & 33,455 & 0 \\
\hline 32 & 0 & 0 & 0 & 0 & 0 & 0 & 0 & 0 & 0 & 0 & 35,174 & 62,984 & 65,725 & 70,801 & 76,560 & 78,682 & 35,481 \\
\hline 33 & 0 & 0 & 0 & 0 & 0 & 0 & 0 & 0 & 0 & 0 & 0 & 36,591 & 64,851 & 69,775 & 71,776 & 77,442 & 83,698 \\
\hline 34 & 0 & 0 & 0 & 0 & 0 & 0 & 0 & 0 & 0 & 0 & 0 & 0 & 37,435 & 68,664 & 70,477 & 72,513 & 82,134 \\
\hline 35 & 0 & 0 & 0 & 0 & 0 & 0 & 0 & 0 & 0 & 0 & 0 & 0 & 0 & 67,728 & 69,581 & 71,128 & 76,954 \\
\hline 36 & 0 & 0 & 0 & 0 & 0 & 0 & 0 & 0 & 0 & 0 & 0 & 0 & 0 & 39,216 & 68,440 & 70,491 & 75,411 \\
\hline 37 & 0 & 0 & 0 & 0 & 0 & 0 & 0 & 0 & 0 & 0 & 0 & 0 & 0 & 0 & 39,662 & 69,104 & 74,672 \\
\hline 38 & 0 & 0 & 0 & 0 & 0 & 0 & 0 & 0 & 0 & 0 & 0 & 0 & 0 & 0 & 0 & 39,863 & 73,389 \\
\hline 39 & 0 & 0 & 0 & 0 & 0 & 0 & 0 & 0 & 0 & 0 & 0 & 0 & 0 & 0 & 0 & 0 & 42,344 \\
\hline total & 107,218 & 144,440 & 195,960 & 278,308 & 312,687 & 328,522 & 363,508 & 386,879 & 394,543 & 423,086 & 435,160 & 458,726 & 474,710 & 500,629 & 507,119 & 512,678 & 544,083 \\
\hline
\end{tabular}

Table 4: Size of The DATABASE, By YeAR AND OBSERVED WORKER AGE 
Another check on the dataset was conducted by tracking those workers who were actually observed in employment in 1987. Table 5 reports the share of individuals observed working in subsequent years, separately for each age. In the following year, 1988, around $70 \%$ of the workers were still observed employed, a percentage that is however lower for the group that reached the age of 20 or 21 and was thus hit by the compulsory military draft (in this case, the values are $66 \%$ and $63 \%$, respectively). Other than the military draft, a wide array of factors could lead to dropping out of the database in a particular year: unemployment, which reached $13 \%$ for young workers in 1988 (UNData, 2009) ${ }^{13}$; having joined an uncovered sector (public administration, in particular ${ }^{14}$ ); having gone back to school ${ }^{15}$. A look at the gender of those not tracked matches what one would expect given the factors that are more likely to pull this set of workers out of employment. Indeed, it is predominantly males, affected by the military draft, who are not tracked in 1988 and 1989. ${ }^{16}$ The dataset also translates with remarkable accuracy the declining unemployment rate between 1996 and 2000 (from $7.3 \%$ to $4.0 \%$, referring now to the overall active population), as it reports an increase in the share of workers under analysis who is captured back in employment. ${ }^{17}$

Even though the focus of the current study is by no means the impact of an increase in the minimum wage on employment, the current population sizes have been checked for consistency with the work by Portugal and Cardoso (2006) on the same data set. Despite the different requirements imposed for sample selection (in Portugal and Cardoso, just the age variable was of concern and thoroughly checked, while here more stringent requirements were imposed on education, gender and the worker identification code), the figures are consistent across the two studies, as employment growth between 1988 and 1989 was sharpest for the age group 17 to 19 years. $^{18}$

\footnotetext{
${ }^{13}$ Refering to workers aged 15 to 24 .

${ }^{14}$ Public administration accounts for approximately $15 \%$ of total employment in Portugal and during the period under analysis its employment level increased by an average 15 thousand workers each year (Castel-Branco et al, 2008: 14-15). Admissions necessarily outweighted this figure, to cover for worker retirement.

$155 \%$ of the workers in the current dataset are observed increasing their level of completed education. In Portugal, the situation of part-time work while studying is very uncommon.

${ }^{16}$ Data not reported, available from the author upon request.

${ }^{17}$ From 1988 to 1992 the youth unemplyment rate also declined, but its effect was partly offset in the dataset by the military draft that affected workers under analysis until 1994.

${ }^{18}$ Portugal and Cardoso concentrated the analysis on a narrower set of workers and legislative changes.
} 


\begin{tabular}{|c|c|c|c|c|c|c|c|c|c|c|c|c|c|c|c|c|c|}
\hline $\begin{array}{c}\text { age in } \\
\text { March } 1987\end{array}$ & 1987 & 1988 & 1989 & 1991 & 1992 & 1993 & 1994 & 1995 & 1996 & 1997 & 1998 & 1999 & 2000 & 2001 & 2003 & 2004 & 2005 \\
\hline 14 & 1.00 & 0.67 & 0.62 & 0.52 & 0.51 & 0.48 & 0.46 & 0.49 & 0.46 & 0.47 & 0.49 & 0.46 & 0.47 & 0.44 & 0.42 & 0.44 & 0.46 \\
\hline 15 & 1.00 & 0.70 & 0.66 & 0.58 & 0.54 & 0.49 & 0.49 & 0.48 & 0.47 & 0.48 & 0.48 & 0.50 & 0.49 & 0.47 & 0.47 & 0.47 & 0.51 \\
\hline 16 & 1.00 & 0.70 & 0.66 & 0.57 & 0.50 & 0.50 & 0.49 & 0.48 & 0.47 & 0.48 & 0.48 & 0.49 & 0.50 & 0.47 & 0.47 & 0.46 & 0.50 \\
\hline 17 & 1.00 & 0.70 & 0.65 & 0.51 & 0.52 & 0.50 & 0.48 & 0.48 & 0.46 & 0.47 & 0.47 & 0.49 & 0.49 & 0.47 & 0.47 & 0.46 & 0.49 \\
\hline 18 & 1.00 & 0.69 & 0.62 & 0.54 & 0.53 & 0.50 & 0.48 & 0.48 & 0.46 & 0.48 & 0.47 & 0.49 & 0.49 & 0.47 & 0.47 & 0.47 & 0.50 \\
\hline 19 & 1.00 & 0.66 & 0.57 & 0.55 & 0.53 & 0.50 & 0.47 & 0.48 & 0.46 & 0.47 & 0.47 & 0.49 & 0.49 & 0.47 & 0.47 & 0.47 & 0.50 \\
\hline 20 & 1.00 & 0.63 & 0.61 & 0.54 & 0.53 & 0.50 & 0.48 & 0.48 & 0.46 & 0.47 & 0.47 & 0.49 & 0.49 & 0.47 & 0.47 & 0.47 & 0.50 \\
\hline
\end{tabular}

Table 5: Share of WORKERS OBSERVEd IN 1987 who ARE TRACKED Later on 
Gross monthly wages were computed as $m w=b w+r e g$, where $b w$ stands for monthly base-wage and reg are other regularly paid benefits. Wages were deflated using the Consumer Price Index (base 2005). Wage outliers ${ }^{19}$ have been dropped. In the analysis, only full-time wage-earners were considered, since the minimum wage is set as a monthly benchmark for full-time work (the database also includes unpaid family members, owners of the firm in case they are actually working in the firm, active working members of cooperatives, etc). The final dataset under analysis therefore consists of 5,161,362 observations on 1,016,866 workers. Table 10 in appendix provides descriptive statistics on the dataset.

\section{Trends in teenage wages under changing minimum wage}

Figures 1 to 5 plot real monthly wage distributions by year and age. ${ }^{20}$ To avoid cluttering more the graphs, vertical lines on the level of the applicable minimum wage for each distribution have not been drawn. However, it may be helpful to have these references in mind when interpreting the peaks in the distributions and therefore table 6 specifies the level of the real minimum wage applicable to each age in each year plotted.

\begin{tabular}{c||c|c|c|c|c|c|c}
\hline \multicolumn{1}{l||}{ Year } & \multicolumn{7}{c}{ Age Group } \\
\hline & 14 & 15 & 16 & 17 & 18 & 19 & 20 or older \\
\hline \hline 1987 & 166 & 166 & 166 & 249 & 332 & 332 & 332 \\
1988 & & 245 & 245 & 245 & 327 & 327 & 327 \\
1989 & & & 240 & 240 & 320 & 320 & 320 \\
1991 & & & & & 339 & 339 & 339 \\
1992 & & & & & & 345 & 345 \\
\hline
\end{tabular}

Table 6: Real minimum Wage, By year And Age of the Worker (2005 Euro). Source: Own computations based on Portugal, Diário da República, several issues.

\footnotetext{
${ }^{19}$ Wages above 10 times percentile 99.

${ }^{20}$ Kernel density of real monthly wages (2005 Euro) in the range up to 600 Euro, using a common bandwidth (equal to 10).
} 


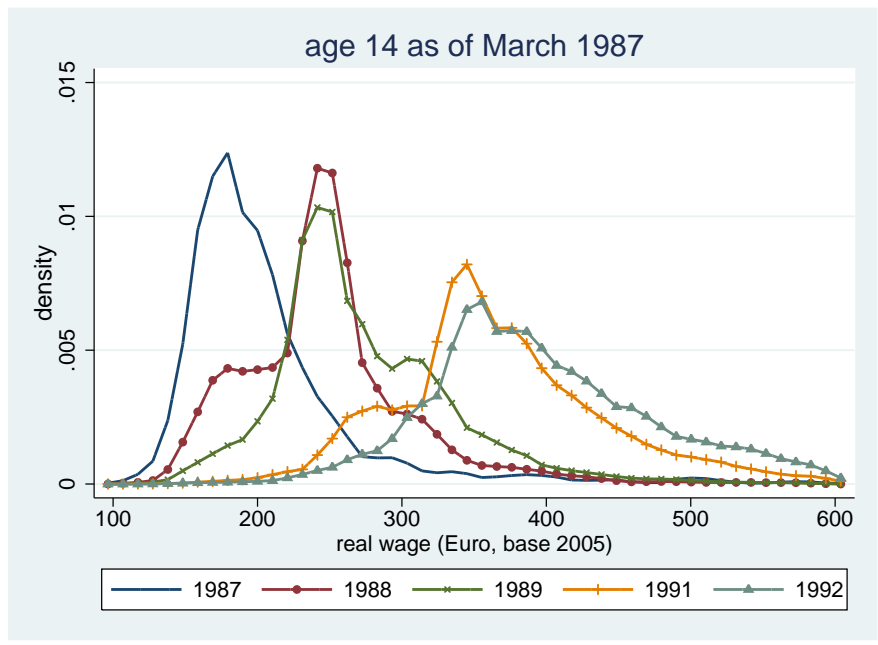

Figure 1: WAGe Distributions, workers AGEd 14 AS OF MARCH 1987. Source: Computations based on Portugal, MTSS.

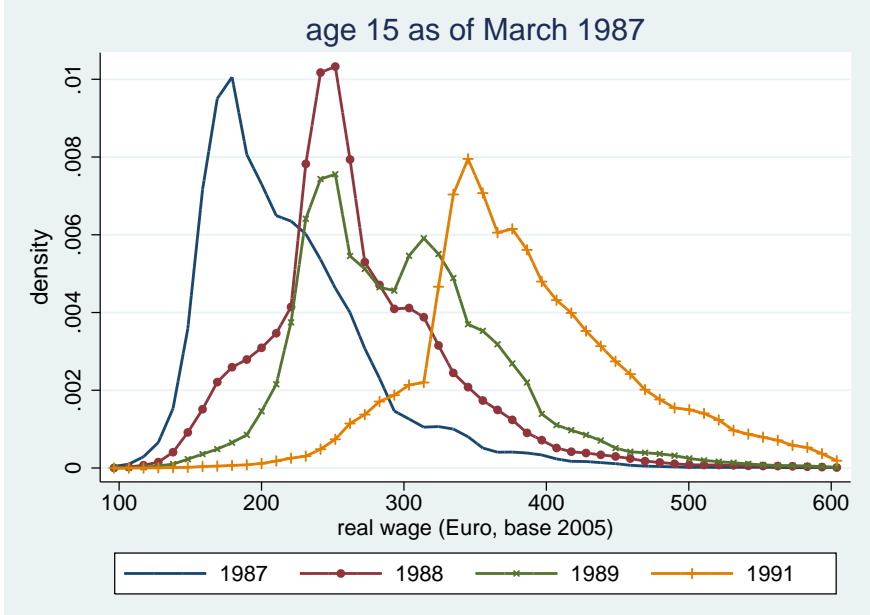

Figure 2: Wage Distributions, WORKERs AGEd 15 AS OF MARCH 1987. Source: Computations based on Portugal, MTSS.

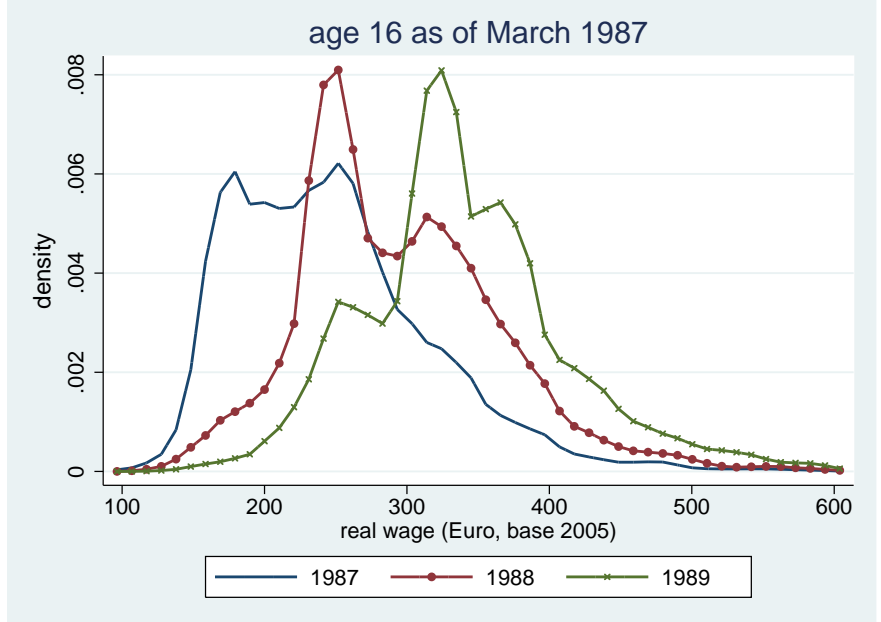

Figure 3: WAGE Distributions, WORKERs AGEd 16 As Of MARCH 1987. Source: Computations based on Portugal, MTSS. 


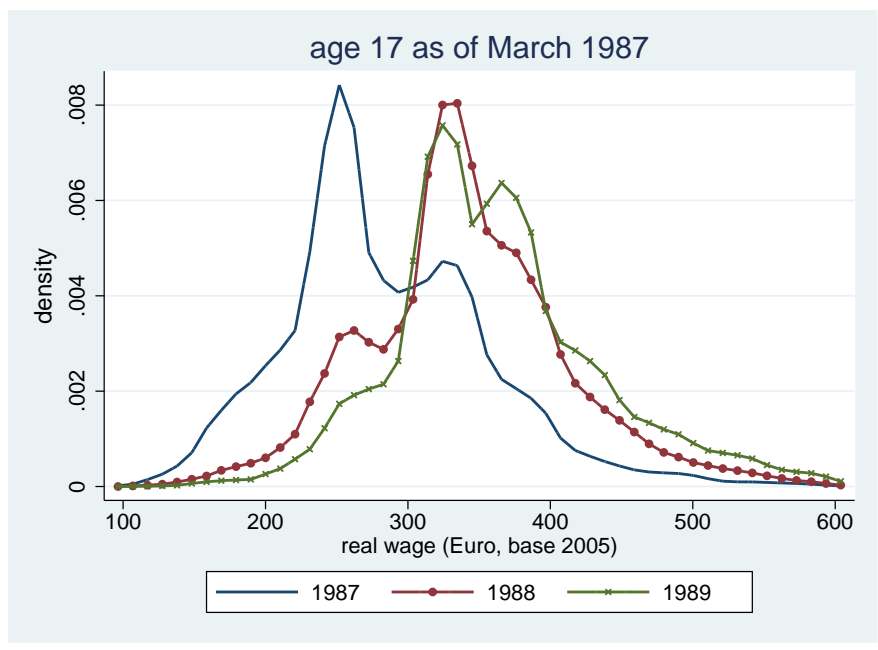

Figure 4: WAGE Distributions, WORKERS AGED 17 AS OF MARCH 1987. Source: Computations based on Portugal, MTSS.

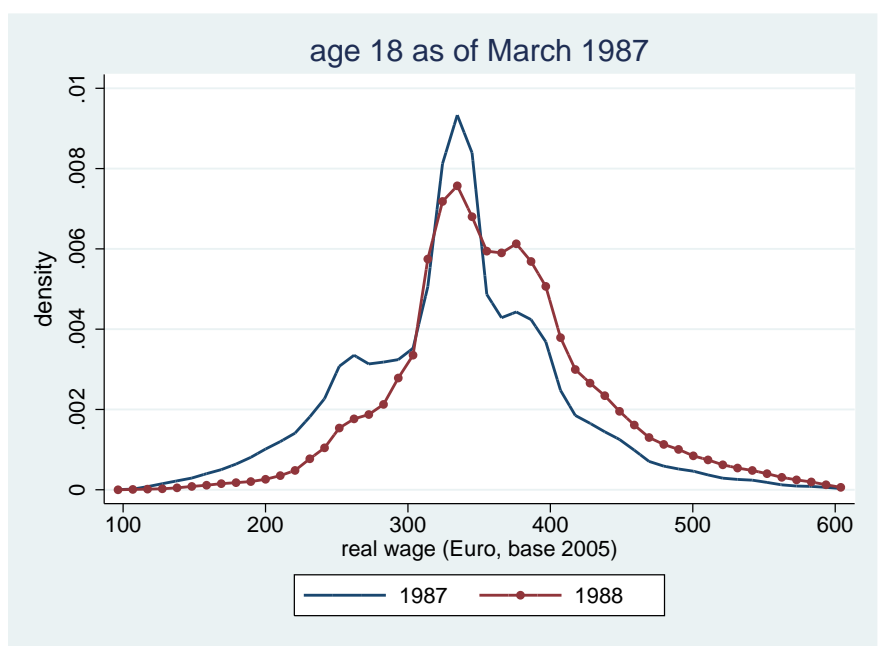

Figure 5: WAGE Distributions, wORkers AGEd 18 AS OF MARCh 1987. Source: Computations based on Portugal, MTSS.

The graphs clearly show a major shift in the wage distribution when the minimum wage for the age group concerned changes. Indeed, the distributions present a clear peak at the mandatory minimum wage level and, as a consequence, whenever the age or legislation underwent change and the age group was eligible for a sharp increase in the minimum wage, the distribution shifted, with a peak at the new minimum wage level. Curiously, in 1987, youngsters aged 16 seem to have benefited from the increase in the minimum wage applicable to the 17 year olds, since their wage distribution presents two peaks, one at their minimum wage level and another at the level enforced for 17 year olds, as if employers had generated a 
spillover effect by treating the two groups as homogeneous. ${ }^{21}$

The fact that minimum wages had such a bite on the wage distribution would render more likely that employers look for compensating mechanisms to accommodate the change in the legislation. Changes in the wage profile of the workers over time are a natural candidate, reinforced by the fact that previous work has shown that employment did not decline for the affected group of workers (Portugal and Cardoso, 2006).

\section{Long-run impact of youth minimum wages}

This section tests whether exposure to high youth minimum wages jeopardizes investment in human capital at young ages, being reflected in lower wages later in life. One main mechanism predicted by the theory will be tested, which unfolds into two different channels: firms could, on the one hand, reduce the provision of firm-specific on-the-job training while, on the other hand, they would upgrade the overall quality of jobs by providing more general on-the-job training. I will test the hypotheses that workers exposed to high minimum wages when young have a flatter tenure-earnings profile, possibly reflecting lower initial investment in firm-specific training, while on the other hand receiving an overall wage premium, reflecting more general on-the-job training. When performing the tests, I will control for the impact of formal investment in human capital by the worker, in the form of schooling.

The unit of analysis is the worker and the longitudinal dataset includes all the available observations on full-time wage-earners who were aged 14 to 20 years as of March 1987.

I start out with a specification of a (log) wage regression where the variable of interest is the contemporaneous level of the minimum wage, after controlling for the age of the worker (to capture labor market experience) and the current year (to capture macroeconomic trends). In the subsequent step, the number of years of exposure to high youth minimum wages is included among the regressors as a set of dummy variables. This preliminary specification of the model is therefore:

$$
W_{i t}=\beta_{1} M W_{i t}+\sum_{e=1}^{5} \beta_{2 e} E_{e i}+\beta_{3}^{\prime} X_{i t}+\varepsilon_{i t},
$$

\footnotetext{
${ }^{21}$ Due to productivity, equity or whichever other reasons.
} 
where $W$ is (log) real wage, $i$ stands for the worker, and $t$ for the year. $M W$ is the log of the real minimum wage enforced for the worker's particular age and it captures the contemporaneous impact of the minimum wage. $E_{e}$ is a dummy variable equal to one if the worker was exposed during $e$ years in his teenagehood to a high minimum wage; both alternatives of potential exposure and actual exposure will be considered, either one ranging from no exposure (the omitted category) to 5 years of exposure. Following table 2, potential exposure is set at 5 years for workers aged 14 as of March 1987, at 4 years for those aged 15 and at 3 years for those aged 16 or 17; it is 2 and 1 years for workers aged 18 or 19, respectively; workers aged 20 as of March 1987 were never eligible to the minimum wage hikes described and thus were never exposed to high youth minimum wages. Actual exposure takes into account the worker's age and year of entry into the labor market and its coding follows table 3. $X$ includes as control variables a set of dummy variables for the current age of the worker and a set of dummy variables for the year of observation. Throughout the analysis, robust standard errors are computed, with clustering at the individual level, since every individual is observed several times and the assumption of independence of observations must therefore be relaxed.

The subsequent steps in the analysis concentrate only on the more relevant measure of exposure to high youth minimum wages - actual exposure - , to explore the mechanisms that may lead minimum wages into having an impact on longer-term wages, by bringing into the picture the schooling level of the worker and the returns to seniority within the firm. A more complete specification of the model is thus the following:

$$
W_{i t}=\alpha_{1} M W_{i t}+\sum_{e=1}^{5} \alpha_{2 e} E_{e i}+\alpha_{3}^{\prime} S_{i t}+\alpha_{4}^{\prime} T_{i t}+\alpha_{5}^{\prime} X_{i t}+v_{i t},
$$

with $S$ as a set of schooling dummy variables, $T$ a set of dummy variables representing tenure (years of seniority within the firm), and the remaining variables keeping their meaning from the previous equation.

To explore the impact of minimum wages on the tenure-earnings profile, the next step consists on interacting tenure within the firm with exposure to high youth minimum wages (a dummy variable achieving the value one if the worker was exposed, and zero otherwise). It is feasible to go still one step further, by interacting tenure with the number of years of exposure to high youth minimum wages (instead of just the dummy variable on exposed or not). By keeping tenure 
and exposure to youth minimum wages as two full sets of dummy variables, no functional form assumptions are imposed on the relationship between tenure and wages for the different groups of workers. Note that, unfortunately, in the case of age such exercise is not feasible and we cannot explore the age-earnings profile to identify at which point in the individual's working life a potential premium or penalty on exposure to youth minimum wages is earned. Indeed, the regression already includes controls for the age of the worker, the year of observation, and the contemporaneous level of the minimum wage applicable in each year to workers of each age. The identification of the contemporaneous impact of minimum wages relies on its variation within year for different ages (up to adulthood or 19 years of age), which renders unfeasible further introducing interactions between exposure to minimum wage and the age of the worker.

The analysis undertaken does not address the unsettled debate on the returns to tenure (see Mincer and Jovanovich (1981), Altonji and Shakotko (1987), Abraham and Farber (1987), Topel (1991) and Wachter (forthcoming)). While it would be desirable to account for worker unobserved quality, that is not feasible in the current setting, as it would wipe out the main variable of interest (exposure to high youth minimum wages), which is a constant within worker. It should nevertheless be underlined that the current analysis: uses one single method to compare the returns to tenure across groups of workers; relies on data for which measurement errors are of little concern; imposes no functional form assumptions on the seniority-wage relationship.

Table 7 reports the main results using potential exposure and table 8 reports the main results with actual exposure to high youth minimum wages. Tables 11 and 12 in appendix list an extended set of estimates.

Table 7: Wage regressions (using potential exposure to youth minimum wage)

\begin{tabular}{lrrrrr}
\hline & $(1)$ & $(2)$ & $(3)$ & $(4)$ & $(5)$ \\
\hline Minimum wage $(\log )$ & .211 & .197 & .215 & .207 & .211 \\
& $(.007)^{* * *}$ & $(.008)^{* * *}$ & $(.008)^{* * *}$ & $(.008)^{* * *}$ & $(.008)^{* * *}$ \\
Potential exposure & & & & & \\
1 year & & -.008 & -.010 & -.008 & -.006 \\
& & $(.002)^{* * *}$ & $(.002)^{* * *}$ & $(.002)^{* * *}$ & $(.002)^{* * *}$ \\
2 years & -.010 & -.018 & -.015 & -.012 \\
& & $(.003)^{* * *}$ & $(.002)^{* * *}$ & $(.002)^{* * *}$ & $(.002)^{* * *}$ \\
3 years & -.010 & -.030 & -.026 & -.022 \\
& & $(.004)^{* *}$ & $(.003)^{* * *}$ & $(.003)^{* * *}$ & $(.003)^{* * *}$ \\
4 years & -.003 & -.038 & -.032 & -.028 \\
& & $(.006)$ & $(.004)^{* * *}$ & $(.004)^{* * *}$ & $(.004)^{* * *}$ \\
\hline
\end{tabular}




\begin{tabular}{|c|c|c|c|c|c|}
\hline & $(1)$ & $(2)$ & $(3)$ & $(4)$ & $(5)$ \\
\hline 5 years & & $\begin{array}{l}-.003 \\
(.006)\end{array}$ & $\begin{array}{r}-.042 \\
(.005)^{* * *}\end{array}$ & $\begin{array}{r}-.035 \\
(.005)^{* * *}\end{array}$ & $\begin{array}{r}-.031 \\
(.004)^{* * *}\end{array}$ \\
\hline \multicolumn{6}{|l|}{ Education } \\
\hline 4 years & & & $\begin{array}{r}.028 \\
(.003)^{* * *}\end{array}$ & $\begin{array}{r}.019 \\
(.003)^{* * *}\end{array}$ & $\begin{array}{r}.041 \\
(.003)^{* * *}\end{array}$ \\
\hline 6 years & & & $\begin{array}{r}.099 \\
(.003)^{* * *}\end{array}$ & $\begin{array}{r}.088 \\
(.003)^{* * *}\end{array}$ & $\begin{array}{r}.118 \\
(.003)^{* * *}\end{array}$ \\
\hline 9 years & & & $\begin{array}{r}.250 \\
(.003)^{* * *}\end{array}$ & $\begin{array}{r}.250 \\
(.003)^{* * *}\end{array}$ & $\begin{array}{r}.279 \\
(.003)^{* * *}\end{array}$ \\
\hline high school & & & $\begin{array}{r}.467 \\
(.003)^{* * *}\end{array}$ & $\begin{array}{r}.466 \\
(.003)^{* * *}\end{array}$ & $\begin{array}{r}.516 \\
(.003)^{* * *}\end{array}$ \\
\hline university & & & $\begin{array}{r}1.030 \\
(.003)^{* * *}\end{array}$ & $\begin{array}{r}1.044 \\
(.003)^{* * *}\end{array}$ & $\begin{array}{r}1.095 \\
(.003)^{* * *}\end{array}$ \\
\hline Female & & & & & $\begin{array}{r}-.220 \\
(.0007)^{* * *}\end{array}$ \\
\hline Year (dummies) & yes & yes & yes & yes & yes \\
\hline Age (dummies) & & yes & yes & yes & yes \\
\hline Tenure (dummies) & & & & yes & yes \\
\hline Const. & $\begin{array}{r}4.226 \\
(.039)^{* * *}\end{array}$ & $\begin{array}{r}4.300 \\
(.041)^{* * *}\end{array}$ & $\begin{array}{r}4.185 \\
(.041)^{* * *}\end{array}$ & $\begin{array}{r}4.200 \\
(.040)^{* * * *}\end{array}$ & $\begin{array}{r}4.245 \\
(.043)^{* * *}\end{array}$ \\
\hline Obs. & 5161362 & 5161362 & 5161362 & 5118561 & 5118561 \\
\hline$R^{2}$ & .212 & .212 & .49 & .502 & .545 \\
\hline$F$ statistic & 23333.66 & 20858.71 & 28659.08 & 20118.76 & 20012.06 \\
\hline
\end{tabular}

Column 1 considers simply the contemporaneous effect of the legal minimum wage on workers' wages and time dummies. The estimated elasticity of wages with respect to the minimum wage is 0.21 and, interestingly, macroeconomic forces captured by the time dummy variables and the contemporaneous level of the minimum wage already account for $21 \%$ of the variation of wages across these individuals, reflecting the relevance of the minimum wage for the population under analysis. Column 2 further introduces the number of years of potential exposure to high youth minimum wages among the explanatory variables, to capture the long-term impact of minimum wages. This preliminary result would suggest that longer exposure to minimum wages during youth is associated with lower wages later in life, even though the impact is not statistically significant for longer exposures (4 or 5 years). The negative impact of potential exposure to youth minimum wages is reinforced after the introduction of controls for the worker's schooling level. That is understandable, given that younger cohorts have higher schooling levels and higher potential exposure (i.e. eligibility) to youth minimum wages; the omission of schooling, which has a positive impact on wages and is positively correlated with exposure, leads to an upward bias in the estimation of the coefficients on expo- 
sure in column 2. After controlling for the contemporaneous impact of minimum wages and worker's education level, one year of potential exposure to high youth minimum wages would reduce wages by $1 \%$, and two, three, four or five years of potential exposure would reduce wages by $1.8 \%, 3 \%, 3.8 \%$ and $4.2 \%$, respectively. Column 3 also reports high returns to university education, consistent with previous studies on the issue (see for example Machado and Mata (2001) and Pereira and Martins (2002)). The results on potential exposure to minimum wages are also robust to the inclusion of the seniority of the worker among the regressors (column 4) and when allowing wages to differ between males and females (column 5 ). In this final specification in table 7 , the negative impact of potential exposure to high youth minimum wages ranges from $0.6 \%$ for workers exposed for one year to $3.1 \%$ for workers exposed for five years. Results on both the elasticity and the negative impact of potential exposure to youth minimum wages on longer-term wages are in line with Neumark and Nizalova (2007).

A more meaningful concept would take into account, not potential eligibility to earn a minimum wage, but the actual exposure once the worker entered the labor market.

Table 8: Wage regressions (using actual exposure to youth minimum wage)

\begin{tabular}{|c|c|c|c|c|c|}
\hline & $(1)$ & $\overline{(2)}$ & $\overline{(3)}$ & (4) & $(5)$ \\
\hline Minimum wage (log) & $\begin{array}{r}.211 \\
(.007)^{* * *}\end{array}$ & $\begin{array}{r}.176 \\
(.008)^{* * *}\end{array}$ & $\begin{array}{r}.209 \\
(.008)^{* * *}\end{array}$ & $\begin{array}{r}.209 \\
(.008)^{* * *}\end{array}$ & $\begin{array}{r}.191 \\
(.009)^{* * *}\end{array}$ \\
\hline $\begin{array}{l}\text { Actual exposure } \\
1 \text { year }\end{array}$ & & $\begin{array}{r}-.133 \\
(.001)^{* * *}\end{array}$ & $\begin{array}{r}.039 \\
(.001)^{* * *}\end{array}$ & $\begin{array}{r}.020 \\
(.001)^{* * *}\end{array}$ & $\begin{array}{r}.012 \\
(.001)^{* * *}\end{array}$ \\
\hline 2 years & & $\begin{array}{r}-.168 \\
(.001)^{* * *}\end{array}$ & $\begin{array}{r}.047 \\
(.001)^{* * *}\end{array}$ & $\begin{array}{r}.024 \\
(.001)^{* * *}\end{array}$ & $\begin{array}{r}.012 \\
(.001)^{* * *}\end{array}$ \\
\hline 3 years & & $\begin{array}{r}-.188 \\
(.002)^{* * *}\end{array}$ & $\begin{array}{r}.057 \\
(.001)^{* * *}\end{array}$ & $\begin{array}{r}.029 \\
(.001)^{* * *}\end{array}$ & $\begin{array}{r}.019 \\
(.001)^{* * *}\end{array}$ \\
\hline 4 years & & $\begin{array}{r}-.207 \\
(.002)^{* * *}\end{array}$ & $\begin{array}{r}.070 \\
(.002)^{* * *}\end{array}$ & $\begin{array}{r}.036 \\
(.002)^{* * *}\end{array}$ & $\begin{array}{r}.031 \\
(.002)^{* * *}\end{array}$ \\
\hline 5 years & & $\begin{array}{r}-.211 \\
(.003)^{* * *}\end{array}$ & $\begin{array}{r}.080 \\
(.003)^{* * *}\end{array}$ & $\begin{array}{r}.040 \\
(.003)^{* * *}\end{array}$ & $\begin{array}{r}.041 \\
(.003)^{* * *}\end{array}$ \\
\hline $\begin{array}{l}\text { Education } \\
4 \text { years }\end{array}$ & & & $\begin{array}{r}.021 \\
(.003)^{* * *}\end{array}$ & $\begin{array}{r}.015 \\
(.003)^{* * *}\end{array}$ & $\begin{array}{r}.039 \\
(.003)^{* * *}\end{array}$ \\
\hline 6 years & & & $\begin{array}{r}.089 \\
(.003)^{* * *}\end{array}$ & $\begin{array}{r}.084 \\
(.003)^{* * *}\end{array}$ & $\begin{array}{r}.115 \\
(.003)^{* * *}\end{array}$ \\
\hline 9 years & & & $\begin{array}{r}.253 \\
(.003)^{* * *}\end{array}$ & $\begin{array}{r}.251 \\
(.003)^{* * *}\end{array}$ & $\begin{array}{r}.280 \\
(.003)^{* * *}\end{array}$ \\
\hline high school & & & $\begin{array}{r}.475 \\
(.003)^{* * * *}\end{array}$ & $\begin{array}{r}.470 \\
(.003)^{* * *}\end{array}$ & $\begin{array}{r}.518 \\
(.003)^{* * *}\end{array}$ \\
\hline university & & & $\begin{array}{r}1.040 \\
(.003)^{* * *}\end{array}$ & $\begin{array}{r}1.049 \\
(.003)^{* * *}\end{array}$ & $\begin{array}{r}1.098 \\
(.003)^{* * *}\end{array}$ \\
\hline Female & & & & & -.220 \\
\hline
\end{tabular}




\begin{tabular}{|c|c|c|c|c|c|}
\hline & $(1)$ & $(2)$ & $(3)$ & $(4)$ & $(5)$ \\
\hline & & & & & $(.0007)$ \\
\hline Year (dummies) & yes & yes & yes & yes & yes \\
\hline Age (dummies) & & yes & yes & yes & yes \\
\hline Tenure (dummies) & & & & yes & yes \\
\hline Const. & $\begin{array}{r}4.226 \\
(.039)^{* * *}\end{array}$ & $\begin{array}{r}4.613 \\
(.042)^{* * *}\end{array}$ & $\begin{array}{r}4.102 \\
(.043)^{* * *}\end{array}$ & $\begin{array}{r}4.123 \\
(.042)^{* * *}\end{array}$ & $\begin{array}{r}4.279 \\
(.044)^{* * *}\end{array}$ \\
\hline Obs. & 5161362 & 5161362 & 5161362 & 5118561 & 5118561 \\
\hline$R^{2}$ & .212 & .229 & .491 & .502 & .545 \\
\hline$F$ statistic & 23333.66 & 22073.04 & 28966.96 & 20229.63 & 20139.98 \\
\hline
\end{tabular}

Results diverge once actual exposure is considered. Table 8 starts out reporting a sharper negative impact of actual exposure to high youth minimum wages on long-term wages than when potential exposure was considered (column 2). Column 3 progresses to control for one of the mechanisms that may drive a negative impact of youth minimum wages on longer-term outcomes. Controlling for the schooling level of the worker indeed reverses the results, revealing a positive impact of actual exposure to high youth minimum wages. Again here, the result is understandable. Individuals with longer actual exposure to youth minimum wages have joined the labor market earlier in their lives, reducing investment in schooling. Given that schooling has a positive impact on wages, the negative correlation between schooling and actual exposure introduces a downward bias in the estimation of the returns to actual exposure when schooling is omitted from the regression. Once we control for the schooling of the worker and the contemporaneous effect of minimum wages, we find that one year of actual participation in the labor market with high youth minimum wages increases future wages by $3.9 \%$ and two, three, four and five years of actual exposure increase future wages by $4.7 \%, 5.7 \%, 7 \%$ and $8 \%$, respectively. That positive link between actual exposure and long-term wages is robust to the introduction of seniority (column 4) and gender (column 5) among the explanatory variables. In the final specification in table table 8 , the positive impact of potential exposure to high youth minimum wages ranges from $1.2 \%$ for workers exposed for one year to $4.1 \%$ for workers exposed for five years.

The difference in results between tables 7 and 8 stresses that eligibility to earn a minimum wage (potential exposure) is a misleading proxy for actual exposure to youth minimum wages, once we aim at evaluating its long-term impact on wages. The empirical literature on this topic had so far relied exclusively on potential 
exposure, in an analysis moreover conducted at the very aggregate level of cells defined by state-year-age (Neumark and Nizalova, 2007). The previous results uncover a link that had not been detected in the previous literature, constrained as it was by data limitations: as opposed to potential exposure, actual exposure to high youth minimum wages can have a positive impact on longer-term wages.

To the extent that minimum wages could drive teenagers to invest less in schooling, they would have a negative impact on future wages, specially in a framework of high returns to education such as in Portugal. However, no causal link between minimum wages and schooling can in the current setting be claimed.

To try to detect the sources of the positive impact of youth minimum wages on long-term wages, I now explore the tenure-earnings profile of groups of workers who underwent different exposure to youth minimum wages. First, tenure is interacted with a dummy variable equal to one for workers exposed as teenagers to high youth minimum wages. The results are reported in table 9, column 1 , and in figure 6 , since a graphical representation of the estimated coefficients on the interaction of tenure with exposure yields a clearer view of the pattern. The results are striking. Figure 6 shows a clearly flatter seniority-wage profile for workers exposed to high youth minimum wages, consistent with a reduction in firm-specific human capital early in the career, while table 9 reveals a robust wage premium for exposed workers, consistent with an upgrading of the quality of jobs offered by firms and an increase in general human capital following the increase in the minimum wage. The tenure-wage profiles diverge up to a tenure of 13 years, at which point a worker never exposed to high youth minimum wages earns $12 \%$ more than an exposed worker; at tenure equal to one year, such difference was $1 \%$ and at 19 years of tenure it is again down to $6 \%$. After we control for the different tenure profiles of workers exposed and not exposed to youth minimum wages, we find the overall long-term wage premium ranging from $5.6 \%$ for workers exposed for one year to $9.1 \%$ for those exposed for five years. 
Table 9: Wage regressions with exposure to high youth minimum wages interacted with tenure

\begin{tabular}{lrr}
\hline & \multicolumn{1}{c}{$(1)$} & \multicolumn{1}{c}{$(2)$} \\
\hline Minimum wage $(\log )$ & .196 & .181 \\
& $(.009)^{* * *}$ & $(.009)^{* * *}$ \\
Exposure high youth min wage & & \\
1 year & .056 & .051 \\
& $(.001)^{* * *}$ & $(.001)^{* * *}$ \\
& .058 & .062 \\
3 years & $(.001)^{* * *}$ & $(.001)^{* * *}$ \\
& .066 & .071 \\
4 years & $(.001)^{* * *}$ & $(.002)^{* * *}$ \\
& .078 & .080 \\
5 years & $(.002)^{* * *}$ & $(.002)^{* * *}$ \\
Education & .091 & .101 \\
4 years & $(.003)^{* * *}$ & $(.004)^{* * *}$ \\
& & \\
6 years & .037 & .037 \\
9 years & $(.003)^{* * *}$ & $(.003)^{* * *}$ \\
& .113 & .113 \\
high school & $(.003)^{* * *}$ & $(.003)^{* * *}$ \\
& .277 & .277 \\
university & $(.003)^{* * *}$ & $(.003)^{* * *}$ \\
& .515 & .515 \\
Female & $(.003)^{* * *}$ & $(.003)^{* * *}$ \\
Year (dummies) & 1.097 & 1.097 \\
Age (dummies) & $(.003)^{* * *}$ & $(.003)^{* * *}$ \\
Tenure (dummies) & -.220 & -.220 \\
Tenure (dummies) $*$ Exposed $(\mathrm{y} / \mathrm{n})$ & $(.0007)^{* * *}$ & $(.0007)^{* * *}$ \\
Const. & yes & yes \\
Obs. & yes & yes \\
$R^{2}$ & yes & yes \\
$F$ statistic & yes & no \\
\hline & 4.205 & yes \\
& 4.270 \\
& $(.044)^{* * *}$ & $(.045)^{* * *}$ \\
& 5118561 & 5118561 \\
& .546 & .546 \\
& 15452.63 & 8501.562 \\
\hline
\end{tabular}

Note: The estimated coefficients on the interaction terms are plotted in figures 6 and 7 .

It is feasible to progress considering a finer partition of actual exposure to youth minimum wages, into a range of one to five years, when interacting it with tenure. Results are now reported in column 2 of table 9 and figure 7 . The pattern reported in the figure is systematic - the longer the exposure to minimum wages, the flatter the seniority-earnings profile. Formal tests indicate that the tenure profiles are significantly different between: workers not exposed to minimum wages and those exposed for any duration (one to five years) of youth minimum wages ${ }^{22}$; workers

\footnotetext{
${ }^{22}$ With the exception of no significant difference in the returns to tenure equal to 2 between workers exposed for 4 years and those not exposed, and the returns to tenure equal to 1,2 or 19 in the case of no exposure and
} 


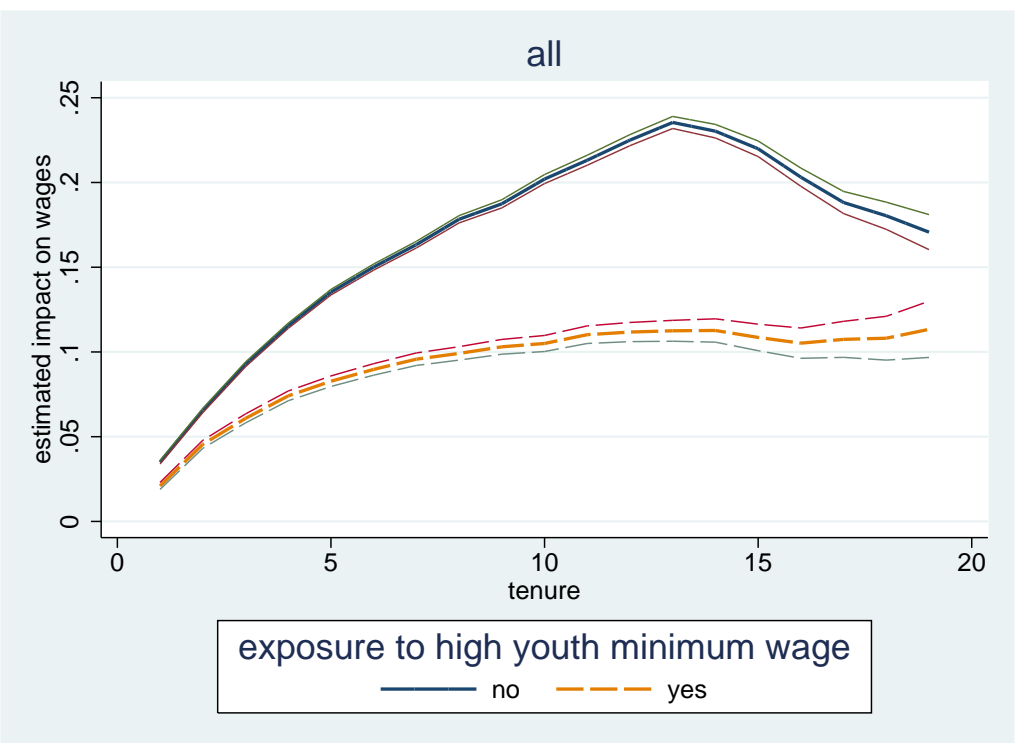

Figure 6: RETURNS TO TENURE FOR WORKERS EXPOSED AND NOT-EXPOSED TO HIGH YOUTH MINIMUM WAGES. Note: The regression controls for: worker's age, schooling, gender and years of actual exposure to youth minimum wages; the contemporaneous level of the minimum wage and year (the main estimates are reported in table 9, column 1). The plot coded as "no exposure" reports the estimated coefficients on the base categories of tenure $t$; the plot coded as "exposed" reports the sum of the estimated coefficient on the base categories of tenure $t$ and the respective interaction with the exposed dummy, so as to yield an immediate interpretation. Returns to tenure in the range 1 to 19 years are plotted. Source: Computations based Portugal, MTSS.

exposed for one year and those exposed for any other duration ${ }^{23}$; workers exposed for two and five years ${ }^{24}$. On the contrary, a formal test on the equality of the coefficients reveals that the returns to tenure are not significantly different among workers exposed for two, three or four years, for most tenure levels. Exposure for three or four years yields tenure returns that are different from those of exposure for five years in about half the cases of tenure between 1 and 19 years. $^{25}$

Table 9 now reports a stronger overall long-term wage premium, rising with the level of exposure to high youth minimum wages. After we control for the different tenure profiles of workers exposed for different durations to youth minimum wages, the overall long-term wage premium ranges from $5.1 \%$ for workers exposed for one year to $10.1 \%$ for those exposed for five years.

Even though not all coefficients on tenure are statistically different across exposure levels, the fact that the flatness of the tenure-earnings profile tends to increase as exposure to youth minimum wages increases, lends some confidence to the result. Similarly, the overall wage premium rising as exposure increases also suggests

\footnotetext{
five years of exposure.

${ }^{23}$ In each case, with two or three levels of tenure as exception.

${ }^{24}$ With the exception of five tenure levels.

${ }^{25}$ All these results are available from the author upon request.
} 


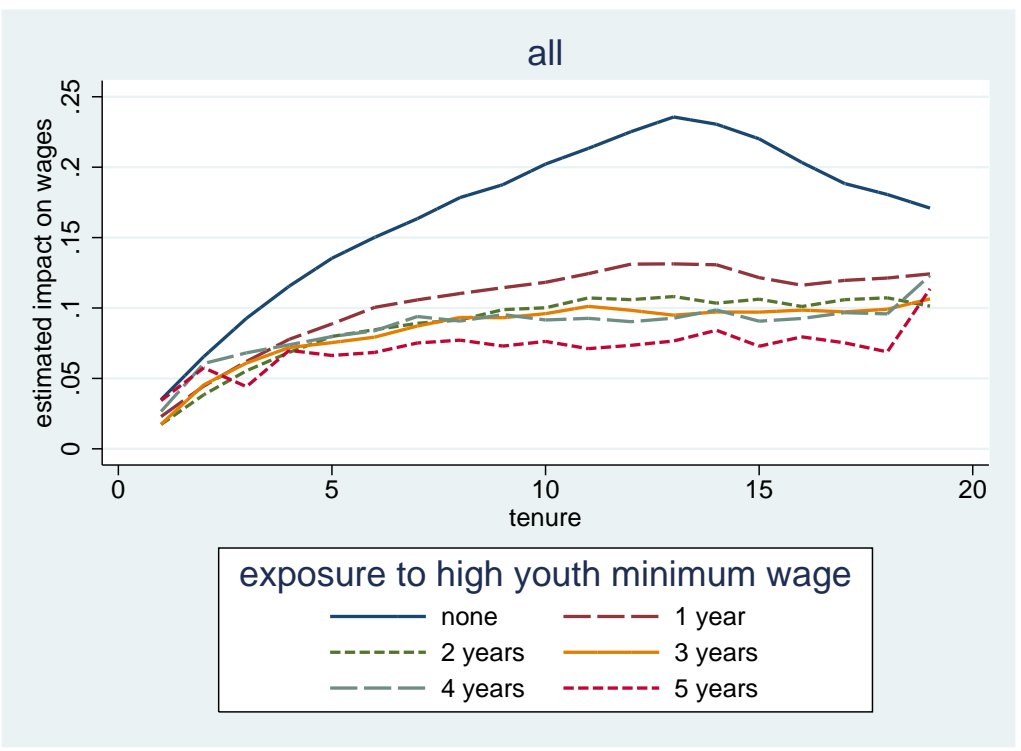

Figure 7: RETURNS TO TENURE FOR WORKERS WITH DIFFERENT LEVELS OF EXPOSURE TO HIGH YOUTH MINIMUM WAGES. Note: The regression controls for worker's age, schooling, gender and years of actual exposure to youth minimum wages; the contemporaneous level of the minimum wage and year (the main estimates are reported in table 9, column 2). The plot coded as "no exposure" reports the estimated coefficients on the base categories of tenure $t$; the plot coded as "exposure $=e$ " reports the sum of the estimated coefficient on the base categories of tenure $t$ and the respective interaction with the dummy variable exposure equal to $e$, so as to yield an immediate interpretation. Returns to tenure in the range 1 to 19 years are plotted. Source: Computations based Portugal, MTSS.

that a relevant pattern has been identified. The current setting does not allow for a test on whether this wage premium is earned at specific stages of the worker's life cycle, since it is not feasible to contrast the age-earnings profile of workers with different exposure to youth minimum wages.

One criticism that could be addressed to these results concerns the fact that job mobility has not been taken into account. The analysis of tenure-wage profiles has implicit a setting of within firm wage growth and one possible reasoning links onthe-job training at the start of an employment spell with wage progression inside that firm. That reasoning and the comparison between trained and not-trained workers would hold as long as workers would stay with the same firm, with the trained ones reaping the benefits of the firm-specific training received. However, taking all workers observed at specific moments in time merges workers at different points in their tenure. A more adequate test would consider only workers observed since the start of a job spell early in their careers and it would use only information referring to that job spell. Figure 8 in the text and table 13 in appendix report the results once the database is restricted to the first job spell we observe from start (tenure equal to zero) for each worker. The aim of this robustness check is 
to get closer to a test on the returns to firm-specific training.
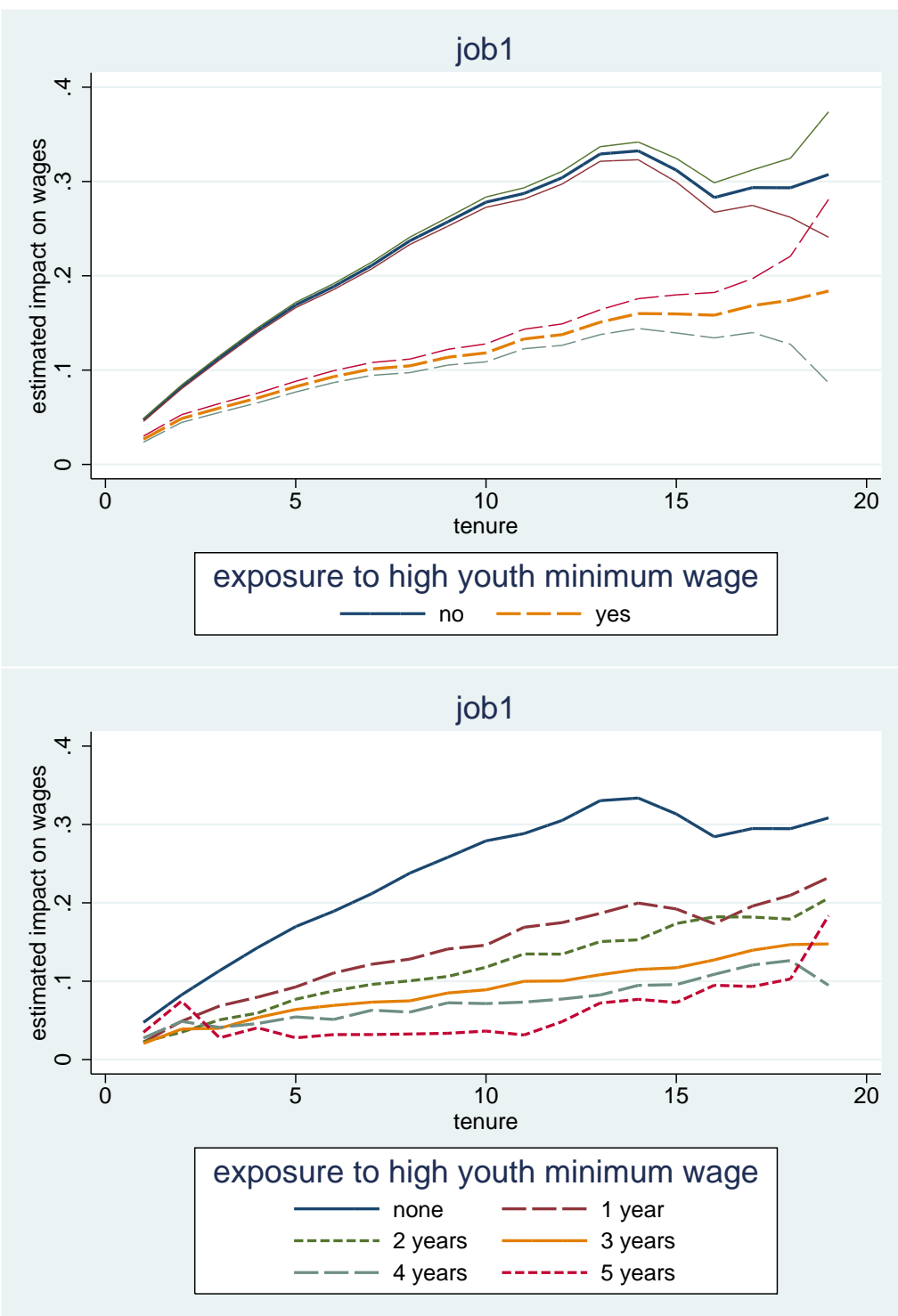

Figure 8: Returns to tenure by Level of exposure to high youth Minimum Wages, FIRST JOB SPELl OBSERVED FROM START. Source: Computations based on Portugal, MTSS. Note: See notes to figures 6 and 7 . The main estimates are reported in table 13 in appendix.

All the previous results are reinforced in this new exercise. Table 13 indicates that the minimum wage benchmark is more relevant in the first job, as the elasticity of wages with respect to the contemporaneous minimum wage is now above 0.20. Comparison of the tenure profiles for the overall group (figure 6) and for the first job tracked from start (figure 8) indicates that wages grow faster in the first job. Looking just at the first job we still find a steeper tenure-earnings profile for workers not subject to high youth minimum wages; moreover, the second panel in the figure still points to an increasingly flatter tenure-earnings profile as exposure 
to youth minimum wages increases, and the difference across exposure groups is now sharper. Table 13 further reports stronger results concerning the overall wage premium: workers exposed to youth minimum wages earn a long-term wage premium, which increases with the duration of exposure, from $5 \%$ for those exposed for one year to $13 \%$ for those exposed for five years to high youth minimum wages.

In synthesis, the two major results standing out from the analysis undertaken are predicted by different bodies of theory. The first pattern, a flatter tenureearnings profile the longer the exposure to minimum wages, is predicted by human capital models and it suggests that investment in firm-specific human capital may have declined following the increase in the minimum wage. The second pattern, a wage premium for workers exposed to high youth minimum wages, that moreover rises with the duration of exposure, is predicted by models of labor market imperfections and wage compression, and it suggests that firms may have upgraded the quality of the jobs they offer and increased investment in the general human capital of their workers following the increase in the minimum wage.

This pattern is also consistent with the results previously reported by Portugal and Cardoso (2006) on increased job attachment by young workers subject to high minimum wages, which could raise their labor market experience, improve their work habits and professional networks, resulting in higher productivity, though not brought about by explicit costly training provided by the firm. Moreover, to the extent that a positive tenure-earning profile can reflect a scheme of delayed payments, as firms try to reduce shirking problems and prevent quits, the increasing job attachment associated with the rise in the minimum wage would allow firms to flatten the tenure-earnings profile. Firms would no longer need to rely so much on the steepness of the earnings profile to motivate their workers to act in line with the firm interest (a point explicitly made by Card and Krueger, 1995: 170).

\section{Conclusion}

Using a remarkable dataset that follows for almost two decades all the workers in the private sector of the economy, the analysis undertaken enables a clear answer to the question: Does exposure to high youth minimum wages have a long-term impact on workers' wages? Moreover, it allows some hints as to the mechanisms that may drive such impact. 
After controlling for the contemporaneous impact of the minimum wage (which translates into an elasticity of approximately 0.20) and the schooling level of the worker, minimum wages have a long-term impact on workers' wages, reflected in: an overall wage premium, consistent with an upgrading of the quality of jobs offered by the firm and a higher level of initial investment in on-the-job general training; a flatter tenure-earnings profile, consistent with a lower level of initial investment in firm-specific training. It is particularly relevant to note that the overall wage premium increases with exposure to youth minimum wages, just like the tenure-earnings profile is flatter the longer the exposure to youth minimum wages. These patterns on the monotonicity of the impact of exposure to minimum wages on later wages are reassuring as to the reliability of the results.

While it can be argued that the flatter wage profile may be a simple consequence of higher wages when young — as firms would compensate a higher initial wage with a slower wage progression, even in the absence of any change in the provision of on-the-job training - it seems harder to argue why firms would pay a long-term wage premium to workers exposed to high youth minimum wages, if the type of jobs they offered or the amount of general human capital they embody in the worker had not changed. Nevertheless, the analysis undertaken does not rule out the possibility that, following such a sharp increase in the minimum wage, firms may have altered their wage policies in more complex ways than predicted when concentrating only on the provision of on-the-job-training. If adopting a system of delayed payment or if providing some type of wage insurance to their workers, they may have changed altogether the phasing of payments over the worker's life cycle. Factors such as these may have an implication on wage premia and the tenureearnings profile and a more comprehensive model of human capital investment by the firm following an increase in the minimum wage may be called for.

\section{References}

Abraham, Katharine G. And Henry S. Farber (1987). Job duration, seniority, and earnings. American Economic Review, 77(3): 278-297.

Acemoglu, Daron And Jorn-Steffen Pischke (1999). The structure of wages and investment in general training. Journal of Political Economy, 107(3): 539-572. 
Acemoglu, Daron And Jorn-Steffen Pischke (2003). Minimum wages and on-the-job training. Research in Labor Economics, 22: 159-202.

Agell, Jonas And KJell Erik Lommerud (1997). Minimum wages and the incentives for skill formation. Journal of Public Economics, 64: 25-40.

Altonji, Joseph G. And Robert A. Shakotko (1987). Do wages rise with job seniority? Review of Economic Studies, 54(3): 437-459.

Arulampalam, Wiji, Alison L. Booth, and Mark L. Bryan (2004). Training and the new minimum wage. Economic Journal, 114: C87-C94.

Becker, Gary S. (1993, first published in 1964). Human Capital, 3rd edition. Chicago: Chicago U Press.

Booth, Alison L. And Gylfi Zoega (2004). Is wage compression a necessary condition for firm-financed general training? Oxford Economic Papers, 56: 88-97.

Cahuc, Pierre And Philippe Michel (1996). Minimum wage unemployment and growth. European Economic Review, 40: 1463-1482.

Campolieti, Michele, Tony Fang, and Morley Gunderson (2005). How minimum wages affect schooling-employment outcomes in Canada, 1993-1999. Journal of Labor Research, 36(3): 533-545.

Card, David and Alan B. Krueger (1995). Myth and Measurement: The New Economics of the Minimum Wage. Princeton; NJ: Princeton University Press.

Castel-Branco, Teresa, Carlos Carinhas e Emilia Cruz (2008). Caracterização dos Recursos Humanos da Administração Pública Portuguesa 2005. Lisboa: Direcção-Geral da Administração e do Emprego Público, Ministério das Finanças e da Administração Pública.

EhrenberG, Ronald G. And Alan J. Marcus (1982). Minimum wages and teenagers' enrollment-employment outcomes: a multinomial logit model. Journal of Human Resources, 17(1): 39-58.

Fairris, David And Roberto Pedace (2004). The impact of minimum wages on job training: an empirical exploration with establishment data. Southern Economic Journal, 70(3): 566-583. 
Grossberg, Adam J. And Paul Sicilian (1999). Minimum wages, on-the-job training, and wage growth. Southern Economic Journal, 65(3): 539-556.

Hashimoto, Masanori (1982). Minimum wage effects on training on the job. American Economic Review, 72(5): 1070-1087.

Hyslop, Dean and Steven Stillman (2007). Youth minimum wage reform and the labour market in New Zealand. Labour Economics, 14(2): 201-230.

Machado, José A. F. And José Mata (2001). Earnings functions in Portugal 1982-1994: Evidence from quantile regressions. Empirical Economics, 26: $115-134$.

Manning, Alan (2003). Monopsony in Motion: Imperfect Competition on Labor Markets. Princeton: Princeton University Press.

Neumark David and Olena Nizalova (2007). Minimum wage effects in the longer run. Journal of Human Resources, 42(2): 435-452.

Neumark, David and William Wascher (1995). Minimum wage effects on employment and school enrollment. Journal of Business and Economic Statistics, 13(2): 199-206.

Neumark, David and William Wascher (1996). The effects of minimum wages on teenage employment and enrollment: Evidence from matched CPS surveys. Research in Labor Economics, 15: 25-63.

Neumark, David and William Wascher (2001). Minimum wages and training revisited. Journal of Labor Economics, 19(2): 563-595.

Pereira, Sonia C. (2003). The impact of minimum wages on youth employment in Portugal. European Economic Review, 47(2): 229-244.

Pereira, Pedro Telhado And Pedro Silva Martins (2002). Education and earnings in Portugal. Conference on Portuguese Economic Development in the European Space, organized by the Bank of Portugal.

Portugal. Ministério do Trabalho E Da Segurança Social (1987 to 2005). Quadros de Pessoal. Data in magnetic medium.

Portugal, Pedro and Ana Rute Cardoso (2006). Disentangling the minimum wage puzzle: an analysis of worker accessions and separations. Journal of the European Economic Association, 4(5): 988-1013. 
Ravn, Morten O. And Jan Rose Sorensen (1999). Schooling, training, growth and minimum wages. Scandinavian Journal of Economics, 101(3): 441-457.

Simpson, WAYne (1984). An econometric analysis of industrial training in Canada. Journal of Human Resources, 19(4): 435-451.

Stevens, Margaret (1994). A theoretical model of on-the-job training with imperfect competition. Oxford Economic Papers, 46(4): 537-562.

Topel, Robert (1991). Specific capital, mobility, and wages: Wages rise with job seniority. Journal of Political Economy, 99(1): 145-176.

Turner, Mark D. And Berna Demiralp (2001). Do higher minimum wages harm minority and inner-city teens? Review of Black Political Economy, 28(4): 95-121.

UNDATA (2009). "Youth unemployment rate, aged 15-24, by sex (ILO estimates/MDG)." http://data.un.org/Data.aspx?d=ILO\&f=srID\%3A29961, consulted on March 18th, 2009.

WAChter, Till VON (forthcoming). Job displacement and its consequences. In David Marsden and François Rycx (eds.) Wage Structures, Employment Adjustments and Globalization: Evidence from Linked and Firm-level Panel Data. Hampshire, UK: Palgrave Macmillan.

\section{Appendix A: Checks on the dataset}

Observations with missing or invalid worker identification code ${ }^{26}$ have been dropped (6.9\% percent of the observations). Whenever gender or date of birth were reported changing over time or schooling was reported decreasing, corrections were introduced, with the information reported over half the times taken as the correct one. ${ }^{27}$ According to this procedure, 0.8 percent, 2.8 percent and 6.8 percent of the observations in the initial panel have been corrected, respectively for gender, birth date and education. Workers with inconsistent data after the introduction of the previous corrections (in particular because no value was reported more than half the times) were dropped. The whole information on the worker was dropped, whichever the incorrect number of observations identified: 1.6 percent, 1.1 percent

\footnotetext{
${ }^{26}$ For example, the value zero, a sequence of nines, or a code too short.

${ }^{27}$ Note that this requirement is more demanding than just considering the modal value as the accurate one.
} 
and 5.4 percent of the observations, due to inconsistent information on gender, birth date or schooling, respectively. These figures overstate the dimension of the problem, given the choice to drop all the worker history. Workers with missing data after the introduction of the previous corrections were dropped. The share of observations dropped due to missing age or schooling was, respectively, 0.4 percent and 1.9 percent of the initial panel. The checked panel with 1987-2005 data on all age groups included 33,212,289 observations worker-year on 6,288,885 workers.

\section{Appendix B: Descriptive statistics}

Table 10: Descriptive statistics

\begin{tabular}{|c|c|c|c|c|c|c|}
\hline Variable & Mean or \% & Std. Dev. & Variable & $\%$ & Variable & $\%$ \\
\hline Monthly wage (log) & 6.418 & 0.525 & Age (years) & & Tenure (years) & \\
\hline Minimum wage (log) & 5.875 & 0.074 & 15 & 0.002 & 1 & 0.144 \\
\hline Potential exposure & & & 16 & 0.006 & 2 & 0.114 \\
\hline 1 year & 0.147 & & 17 & 0.009 & 3 & 0.093 \\
\hline 2 years & 0.146 & & 18 & 0.016 & 4 & 0.080 \\
\hline 3 years & 0.283 & & 19 & 0.025 & 5 & 0.067 \\
\hline 4 years & 0.140 & & 20 & 0.033 & 6 & 0.056 \\
\hline 5 years & 0.137 & & 21 & 0.030 & 7 & 0.048 \\
\hline Actual exposure & & & 22 & 0.038 & 8 & 0.041 \\
\hline 1 year & 0.110 & & 23 & 0.044 & 9 & 0.034 \\
\hline 2 years & 0.086 & & 24 & 0.055 & 10 & 0.028 \\
\hline 3 years & 0.068 & & 25 & 0.059 & 11 & 0.023 \\
\hline 4 years & 0.032 & & 26 & 0.062 & 12 & 0.020 \\
\hline 5 years & 0.009 & & 27 & 0.065 & 13 & 0.017 \\
\hline Education & & & 28 & 0.067 & 14 & 0.013 \\
\hline 4 years & 0.250 & & 29 & 0.062 & 15 & 0.010 \\
\hline 6 years & 0.310 & & 30 & 0.063 & 16 & 0.007 \\
\hline 9 years & 0.144 & & 31 & 0.064 & 17 & 0.005 \\
\hline high school & 0.201 & & 32 & 0.065 & 18 & 0.003 \\
\hline university & 0.088 & & 33 & 0.060 & 19 & 0.002 \\
\hline Female & 0.455 & & 34 & 0.049 & 20 & 0.001 \\
\hline Year & & & 35 & 0.041 & 21 & 0.001 \\
\hline 1988 & 0.023 & & 36 & 0.036 & 22 & 0.001 \\
\hline 1989 & 0.031 & & 37 & 0.026 & 23 & 0 \\
\hline 1991 & 0.044 & & 38 & 0.016 & 24 & 0 \\
\hline 1992 & 0.05 & & 39 & 0.006 & 25 & 0 \\
\hline 1993 & 0.053 & & & & & \\
\hline 1994 & 0.06 & & & & & \\
\hline 1995 & 0.064 & & & & & \\
\hline 1996 & 0.065 & & & & & \\
\hline 1997 & 0.071 & & & & & \\
\hline 1998 & 0.071 & & & & & \\
\hline 1999 & 0.075 & & & & & \\
\hline 2000 & 0.075 & & & & & \\
\hline 2002 & 0.074 & & & & & \\
\hline 2003 & 0.074 & & & & & \\
\hline 2004 & 0.075 & & & & & \\
\hline 2005 & 0.078 & & & & & \\
\hline \multicolumn{7}{|c|}{$\mathrm{N}=5,161,362$} \\
\hline
\end{tabular}




\section{Appendix C: Additional tables}

Table 11: Wage regressions (using potential exposure to youth minimum wage), extended set of estimates

\begin{tabular}{|c|c|c|c|c|c|}
\hline & $(1)$ & $(2)$ & $(3)$ & $(4)$ & $(5)$ \\
\hline Minimum wage (log) & $\begin{array}{r}.211 \\
(.007)^{* * *}\end{array}$ & $\begin{array}{r}.197 \\
(.008)^{* * *}\end{array}$ & $\begin{array}{r}.215 \\
(.008)^{* * *}\end{array}$ & $\begin{array}{r}.207 \\
(.008)^{* * *}\end{array}$ & $\begin{array}{r}.211 \\
(.008)^{* * *}\end{array}$ \\
\hline \multicolumn{6}{|l|}{ Potential exposure } \\
\hline 1 year & & $\begin{array}{r}-.008 \\
(.002)^{* * *}\end{array}$ & $\begin{array}{r}-.010 \\
(.002)^{* * *}\end{array}$ & $\begin{array}{r}-.008 \\
(.002)^{* * *}\end{array}$ & $\begin{array}{r}-.006 \\
(.002)^{* * *}\end{array}$ \\
\hline 2 years & & $\begin{array}{r}-.010 \\
(.003)^{* * *}\end{array}$ & $\begin{array}{r}-.018 \\
(.002)^{* * *}\end{array}$ & $\begin{array}{r}-.015 \\
(.002)^{* * *}\end{array}$ & $\begin{array}{r}-.012 \\
(.002)^{* * *}\end{array}$ \\
\hline 3 years & & $\begin{array}{c}-.010 \\
(.004)^{* *}\end{array}$ & $\begin{array}{r}-.030 \\
(.003)^{* * *}\end{array}$ & $\begin{array}{r}-.026 \\
(.003)^{* * *}\end{array}$ & $\begin{array}{r}-.022 \\
(.003)^{* * *}\end{array}$ \\
\hline 4 years & & $\begin{array}{l}-.003 \\
(.006)\end{array}$ & $\begin{array}{r}-.038 \\
(.004)^{* * *}\end{array}$ & $\begin{array}{r}-.032 \\
(.004)^{* * *}\end{array}$ & $\begin{array}{r}-.028 \\
(.004)^{* * *}\end{array}$ \\
\hline 5 years & & $\begin{array}{l}-.003 \\
(.006)\end{array}$ & $\begin{array}{r}-.042 \\
(.005)^{* * *}\end{array}$ & $\begin{array}{r}-.035 \\
(.005)^{* * *}\end{array}$ & $\begin{array}{r}-.031 \\
(.004)^{* * *}\end{array}$ \\
\hline \multicolumn{6}{|l|}{ Education } \\
\hline 4 years & & & $\begin{array}{r}.028 \\
(.003)^{* * *}\end{array}$ & $\begin{array}{r}.019 \\
(.003)^{* * *}\end{array}$ & $\frac{.041}{(.003)^{* * *}}$ \\
\hline 6 years & & & $\begin{array}{r}.099 \\
(.003)^{* * *}\end{array}$ & $\begin{array}{r}.088 \\
(.003)^{* * * *}\end{array}$ & $\underset{(.003)^{* * *}}{.118}$ \\
\hline 9 years & & & $\begin{array}{r}.250 \\
(.003)^{* * *}\end{array}$ & $\begin{array}{r}.250 \\
(.003)^{* * *}\end{array}$ & $\begin{array}{r}.279 \\
(.003)^{* * *}\end{array}$ \\
\hline high school & & & $\begin{array}{r}.467 \\
(.003)^{* * * *}\end{array}$ & $\begin{array}{r}.466 \\
(.003)^{* * *}\end{array}$ & $\begin{array}{r}.516 \\
(.003)^{* * *}\end{array}$ \\
\hline university & & & $\begin{array}{r}1.030 \\
(.003)^{* * *}\end{array}$ & $\begin{array}{r}1.044 \\
(.003)^{* * *}\end{array}$ & $\begin{array}{r}1.095 \\
(.003)^{* * *}\end{array}$ \\
\hline \multicolumn{6}{|l|}{ Tenure (years) } \\
\hline 1 & & & & $\begin{array}{r}.028 \\
(.0005)^{* * *}\end{array}$ & $(.0004)^{* * *}$ \\
\hline 2 & & & & $\begin{array}{r}.056 \\
(.0005)^{* * *}\end{array}$ & $\begin{array}{r}.061 \\
(.0005)^{* * *}\end{array}$ \\
\hline 3 & & & & $\begin{array}{r}.079 \\
(.0006)^{* * *}\end{array}$ & $\begin{array}{r}.086 \\
(.0006)^{* * *}\end{array}$ \\
\hline 4 & & & & $\begin{array}{r}.098 \\
(.0006)^{* * *}\end{array}$ & $\begin{array}{r}.106 \\
(.0006)^{* * *}\end{array}$ \\
\hline 5 & & & & $(.0007)^{* * *}$ & $\begin{array}{r}.124 \\
(.0007)^{* * *}\end{array}$ \\
\hline 6 & & & & $\begin{array}{r}.127 \\
(.0008)^{* * *}\end{array}$ & $\begin{array}{r}.137 \\
(.0007)^{* * *}\end{array}$ \\
\hline 7 & & & & $\begin{array}{r}.138 \\
(.0008)^{* * *}\end{array}$ & $\begin{array}{r}.148 \\
(.0008)^{* * *}\end{array}$ \\
\hline 8 & & & & $\begin{array}{r}.149 \\
(.0009)^{* * *}\end{array}$ & $\begin{array}{r}.160 \\
(.0009)^{* * *}\end{array}$ \\
\hline 9 & & & & $\begin{array}{r}.155 \\
(.001)^{* * *}\end{array}$ & $\begin{array}{r}.167 \\
(.001)^{* * *}\end{array}$ \\
\hline 10 & & & & $\begin{array}{r}.165 \\
(.001)^{* * *}\end{array}$ & $\begin{array}{r}.177 \\
(.001)^{* * *}\end{array}$ \\
\hline 11 & & & & $\begin{array}{r}.173 \\
(.001)^{* * *}\end{array}$ & $\begin{array}{r}.185 \\
(.001)^{* * *}\end{array}$ \\
\hline 12 & & & & $\begin{array}{r}.179 \\
(.001)^{* * *}\end{array}$ & $\begin{array}{r}.193 \\
(.001)^{* * *}\end{array}$ \\
\hline 13 & & & & $\begin{array}{r}.186 \\
(.001)^{* * *}\end{array}$ & $\begin{array}{r}.200 \\
(.001)^{* * *}\end{array}$ \\
\hline 14 & & & & $\begin{array}{r}.180 \\
(.002)^{* * *}\end{array}$ & $\begin{array}{r}.195 \\
(.002)^{* * *}\end{array}$ \\
\hline 15 & & & & .170 & .185 \\
\hline
\end{tabular}




\begin{tabular}{|c|c|c|c|c|c|}
\hline & $(1)$ & $(2)$ & $(3)$ & $(4)$ & $(5)$ \\
\hline & & & & $(.002)$ & $(.002)^{1-1}$ \\
\hline 16 & & & & $\begin{array}{r}.158 \\
(.002)^{* * *}\end{array}$ & $\begin{array}{r}.172 \\
(.002)^{* * *}\end{array}$ \\
\hline 17 & & & & $\begin{array}{r}.150 \\
(.002)^{* * *}\end{array}$ & $\begin{array}{r}.163 \\
(.002)^{* * *}\end{array}$ \\
\hline 18 & & & & $\begin{array}{r}.149 \\
(.003)^{* * *}\end{array}$ & $\begin{array}{r}.159 \\
(.003)^{* * *}\end{array}$ \\
\hline 19 & & & & $\begin{array}{r}.150 \\
(.004)^{* * *}\end{array}$ & $\begin{array}{r}.156 \\
(.003)^{* * *}\end{array}$ \\
\hline 20 & & & & $\begin{array}{r}.150 \\
(.004)^{* * *}\end{array}$ & $\begin{array}{r}.153 \\
(.004)^{* * *}\end{array}$ \\
\hline 21 & & & & $\begin{array}{r}.157 \\
(.005)^{* * *}\end{array}$ & $\begin{array}{r}.153 \\
(.005)^{* * *}\end{array}$ \\
\hline 22 & & & & $\begin{array}{r}.161 \\
(.006)^{* * *}\end{array}$ & $\begin{array}{r}.153 \\
(.006)^{* * *}\end{array}$ \\
\hline 23 & & & & $\begin{array}{r}.166 \\
(.009)^{* * *}\end{array}$ & $\begin{array}{r}.152 \\
(.008)^{* * *}\end{array}$ \\
\hline 24 & & & & $\begin{array}{r}.167 \\
(.014)^{* * *}\end{array}$ & $\begin{array}{r}.145 \\
(.013)^{* * *}\end{array}$ \\
\hline 25 & & & & $\begin{array}{r}.214 \\
(.035)^{* * *}\end{array}$ & $\begin{array}{r}.186 \\
(.032)^{* * *}\end{array}$ \\
\hline \multicolumn{6}{|c|}{ Age (years) } \\
\hline 15 & $\begin{array}{r}.067 \\
(.010)^{* * *}\end{array}$ & $\begin{array}{r}.069 \\
(.010)^{* * * *}\end{array}$ & $\begin{array}{r}.056 \\
(.010)^{* * * *}\end{array}$ & $\begin{array}{r}.067 \\
(.008)^{* * *}\end{array}$ & $\begin{array}{r}.070 \\
(.009)^{* * *}\end{array}$ \\
\hline 16 & $\begin{array}{r}.169 \\
(.010)^{* * *}\end{array}$ & $\begin{array}{r}.175 \\
(.010)^{* * *}\end{array}$ & $\begin{array}{r}.152 \\
(.010)^{* * *}\end{array}$ & $\begin{array}{r}.154 \\
(.009)^{* * *}\end{array}$ & $\begin{array}{r}.151 \\
(.010)^{* * *}\end{array}$ \\
\hline 17 & $\begin{array}{r}.254 \\
(.010)^{* * *}\end{array}$ & $\begin{array}{r}.263 \\
(.011)^{* * *}\end{array}$ & $\begin{array}{r}.230 \\
(.011)^{* * *}\end{array}$ & $\begin{array}{r}.227 \\
(.009)^{* * *}\end{array}$ & $\begin{array}{r}.218 \\
(.010)^{* * *}\end{array}$ \\
\hline 18 & $\begin{array}{r}.344 \\
(.011)^{* * *}\end{array}$ & $\begin{array}{r}.358 \\
(.012)^{* * *}\end{array}$ & $\begin{array}{r}.304 \\
(.012)^{* * *}\end{array}$ & $\begin{array}{r}.296 \\
(.010)^{* * *}\end{array}$ & $\begin{array}{r}.284 \\
(.011)^{* * *}\end{array}$ \\
\hline 19 & $\begin{array}{r}.413 \\
(.011)^{* * *}\end{array}$ & $\begin{array}{r}.426 \\
(.013)^{* * * *}\end{array}$ & $\begin{array}{r}.357 \\
(.012)^{* * *}\end{array}$ & $\begin{array}{r}.343 \\
(.011)^{* * *}\end{array}$ & $\begin{array}{r}.332 \\
(.012)^{* * *}\end{array}$ \\
\hline 20 & $\begin{array}{r}.463 \\
(.011)^{* * *}\end{array}$ & $\begin{array}{r}.475 \\
(.013)^{* * *}\end{array}$ & $\begin{array}{r}.385 \\
(.013)^{* * * *}\end{array}$ & $\begin{array}{r}.367 \\
(.011)^{* * *}\end{array}$ & $\begin{array}{r}.363 \\
(.012)^{* * *}\end{array}$ \\
\hline 21 & $\begin{array}{r}.498 \\
(.011)^{* * *}\end{array}$ & $\begin{array}{r}.510 \\
(.014)^{* * *}\end{array}$ & $\begin{array}{r}.399 \\
(.013)^{* * *}\end{array}$ & $\begin{array}{r}.378 \\
(.011)^{* * *}\end{array}$ & $\begin{array}{r}.387 \\
(.012)^{* * *}\end{array}$ \\
\hline 22 & $\begin{array}{r}.547 \\
(.011)^{* * *}\end{array}$ & $\begin{array}{r}.560 \\
(.014)^{* * *}\end{array}$ & $\begin{array}{r}.431 \\
(.013)^{* * *}\end{array}$ & $\begin{array}{r}.409 \\
(.012)^{* * *}\end{array}$ & $\begin{array}{r}.406 \\
(.013)^{* * *}\end{array}$ \\
\hline 23 & $\begin{array}{r}.594 \\
(.011)^{* * *}\end{array}$ & $\begin{array}{r}.607 \\
(.015)^{* * *}\end{array}$ & $\begin{array}{r}.459 \\
(.014)^{* * *}\end{array}$ & $\begin{array}{r}.436 \\
(.012)^{* * *}\end{array}$ & $\begin{array}{r}.428 \\
(.013)^{* * *}\end{array}$ \\
\hline 24 & $\begin{array}{r}.640 \\
(.011)^{* * *}\end{array}$ & $\begin{array}{r}.652 \\
(.016)^{* * *}\end{array}$ & $\begin{array}{r}.481 \\
(.014)^{* * *}\end{array}$ & $\begin{array}{r}.455 \\
(.013)^{* * *}\end{array}$ & $\begin{array}{r}.446 \\
(.013)^{* * *}\end{array}$ \\
\hline 25 & $\begin{array}{r}.684 \\
(.011)^{* * *}\end{array}$ & $\begin{array}{r}.696 \\
(.017)^{* * *}\end{array}$ & $\begin{array}{r}.505 \\
(.015)^{* * *}\end{array}$ & $\begin{array}{r}.476 \\
(.013)^{* * *}\end{array}$ & $\begin{array}{r}.467 \\
(.014)^{* * *}\end{array}$ \\
\hline 26 & $\begin{array}{r}.722 \\
(.011)^{* * *}\end{array}$ & $\begin{array}{r}.734 \\
(.017)^{* * *}\end{array}$ & $\begin{array}{r}.529 \\
(.015)^{* * *}\end{array}$ & $\begin{array}{r}.496 \\
(.014)^{* * *}\end{array}$ & $\begin{array}{r}.486 \\
(.014)^{* * *}\end{array}$ \\
\hline 27 & $\begin{array}{r}.753 \\
(.011)^{* * *}\end{array}$ & $\begin{array}{r}.766 \\
(.018)^{* * * *}\end{array}$ & $\begin{array}{r}.552 \\
(.015)^{* * *}\end{array}$ & $\begin{array}{r}.515 \\
(.014)^{* * *}\end{array}$ & $\begin{array}{r}.504 \\
(.015)^{* * *}\end{array}$ \\
\hline 28 & $\begin{array}{r}.776 \\
(.011)^{* * *}\end{array}$ & $\begin{array}{r}.789 \\
(.019)^{* * *}\end{array}$ & $\begin{array}{r}.574 \\
(.016)^{* * *}\end{array}$ & $\begin{array}{r}.532 \\
(.015)^{* * *}\end{array}$ & $\begin{array}{r}.521 \\
(.015)^{* * *}\end{array}$ \\
\hline 29 & $\begin{array}{r}.794 \\
(.011)^{* * *}\end{array}$ & $\begin{array}{r}.808 \\
(.020)^{* * * *}\end{array}$ & $\begin{array}{r}.595 \\
(.017)^{* * *}\end{array}$ & $\begin{array}{r}.550 \\
(.015)^{* * *}\end{array}$ & $\begin{array}{r}.539 \\
(.016)^{* * *}\end{array}$ \\
\hline 30 & $\begin{array}{r}.806 \\
(.011)^{* * *}\end{array}$ & $\begin{array}{r}.819 \\
(.020)^{* * *}\end{array}$ & $\begin{array}{r}.612 \\
(.017)^{* * *}\end{array}$ & $\begin{array}{r}.564 \\
(.016)^{* * *}\end{array}$ & $\begin{array}{r}.553 \\
(.016)^{* * *}\end{array}$ \\
\hline 31 & $\begin{array}{r}.815 \\
(.011)^{* * *}\end{array}$ & $\begin{array}{r}.827 \\
(.021)^{* * *}\end{array}$ & $\begin{array}{r}.629 \\
(.018)^{* * *}\end{array}$ & $\begin{array}{r}.578 \\
(.017)^{* * *}\end{array}$ & $\begin{array}{r}.567 \\
(.017)^{* * *}\end{array}$ \\
\hline 32 & $\begin{array}{r}.822 \\
(.011)^{* * *}\end{array}$ & $\begin{array}{r}.835 \\
(.022)^{* * *}\end{array}$ & $\begin{array}{r}.643 \\
(.018)^{* * *}\end{array}$ & $\begin{array}{r}.591 \\
(.017)^{* * *}\end{array}$ & $\begin{array}{r}.579 \\
(.017)^{* * *}\end{array}$ \\
\hline
\end{tabular}




\begin{tabular}{lrrrrr}
\hline & $(1)$ & $(2)$ & $(3)$ & $(4)$ & $(5)$ \\
\hline 33 & .825 & .838 & .657 & .602 & .591 \\
34 & $(.011)^{* * *}$ & $(.023)^{* * *}$ & $(.019)^{* * *}$ & $(.018)^{* * *}$ & $(.018)^{* * *}$ \\
& .825 & .839 & .670 & .614 & .603 \\
35 & $(.012)^{* * *}$ & $(.024)^{* * *}$ & $(.019)^{* * *}$ & $(.018)^{* * *}$ & $(.018)^{* * *}$ \\
& .823 & .838 & .681 & .625 & .614 \\
36 & $(.012)^{* * *}$ & $(.025)^{* * *}$ & $(.020)^{* * *}$ & $(.019)^{* * *}$ & $(.019)^{* * *}$ \\
& .824 & .838 & .693 & .635 & .626 \\
37 & $(.012)^{* * *}$ & $(.026)^{* * *}$ & $(.021)^{* * *}$ & $(.020)^{* * *}$ & $(.019)^{* * *}$ \\
& .827 & .839 & .703 & .645 & .637 \\
38 & $(.012)^{* * *}$ & $(.027)^{* * *}$ & $(.021)^{* * *}$ & $(.020)^{* * *}$ & $(.020)^{* * *}$ \\
& .828 & .838 & .711 & .654 & .647 \\
39 & $(.012)^{* * *}$ & $(.028)^{* * *}$ & $(.022)^{* * *}$ & $(.021)^{* * *}$ & $(.020)^{* * *}$ \\
& .835 & .842 & .723 & .665 & .659 \\
Female & $(.013)^{* * *}$ & $(.029)^{* * *}$ & $(.023)^{* * *}$ & $(.022)^{* * *}$ & $(.021)^{* * *}$ \\
& & & & & -.220 \\
Year (dummies) & & & & & $(.0007)^{* * *}$ \\
Const. & yes & yes & yes & yes & yes \\
Obs. & 4.226 & 4.300 & 4.185 & 4.200 & 4.245 \\
$R^{2}$ & $(.039)^{* * *}$ & $(.041)^{* * *}$ & $(.041)^{* * *}$ & $(.040)^{* * *}$ & $(.043)^{* * *}$ \\
$F$ statistic & 5161362 & 5161362 & 5161362 & 5118561 & 5118561 \\
& .212 & .212 & .49 & .502 & .545 \\
& 23333.66 & 20858.71 & 28659.08 & 20118.76 & 20012.06 \\
\hline
\end{tabular}

Table 12: Wage regressions (using actual exposure to youth minimum wage), extended set of estimates

\begin{tabular}{|c|c|c|c|c|c|}
\hline & $(1)$ & $(2)$ & $(3)$ & $(4)$ & $(5)$ \\
\hline Minimum wage $(\log )$ & $\begin{array}{r}.211 \\
(.007)^{* * *}\end{array}$ & $\begin{array}{r}.176 \\
(.008)^{* * *}\end{array}$ & $\begin{array}{r}.209 \\
(.008)^{* * *}\end{array}$ & $\begin{array}{r}.209 \\
(.008)^{* * *}\end{array}$ & $\begin{array}{r}.191 \\
(.009)^{* * *}\end{array}$ \\
\hline $\begin{array}{l}\text { Actual exposure } \\
1 \text { year }\end{array}$ & & $\begin{array}{r}-.133 \\
(.001)^{* * *}\end{array}$ & $\begin{array}{r}.039 \\
(.001)^{* * *}\end{array}$ & $\begin{array}{r}.020 \\
(.001)^{* * *}\end{array}$ & $\begin{array}{r}.012 \\
(.001)^{* * *}\end{array}$ \\
\hline 2 years & & $\begin{array}{r}-.168 \\
(.001)^{* * *}\end{array}$ & $\begin{array}{r}.047 \\
(.001)^{* * *}\end{array}$ & $\begin{array}{r}.024 \\
(.001)^{* * *}\end{array}$ & $\begin{array}{r}.012 \\
(.001)^{* * *}\end{array}$ \\
\hline 3 years & & $\begin{array}{r}-.188 \\
(.002)^{* * *}\end{array}$ & $\begin{array}{r}.057 \\
(.001)^{* * *}\end{array}$ & $\begin{array}{r}.029 \\
(.001)^{* * *}\end{array}$ & $\begin{array}{r}.019 \\
(.001)^{* * *}\end{array}$ \\
\hline 4 years & & $\begin{array}{r}-.207 \\
(.002)^{* * *}\end{array}$ & $\begin{array}{r}.070 \\
(.002)^{* * *}\end{array}$ & $\begin{array}{r}.036 \\
(.002)^{* * *}\end{array}$ & $\begin{array}{r}.031 \\
(.002)^{* * *}\end{array}$ \\
\hline 5 years & & $\begin{array}{r}-.211 \\
(.003)^{* * *}\end{array}$ & $\begin{array}{r}.080 \\
(.003)^{* * *}\end{array}$ & $\begin{array}{r}.040 \\
(.003)^{* * *}\end{array}$ & $\begin{array}{r}.041 \\
(.003)^{* * *}\end{array}$ \\
\hline $\begin{array}{l}\text { Education } \\
4 \text { years }\end{array}$ & & & $\begin{array}{r}.021 \\
(.003)^{* * *}\end{array}$ & $\begin{array}{r}.015 \\
(.003)^{* * *}\end{array}$ & $\begin{array}{r}.039 \\
(.003)^{* * *}\end{array}$ \\
\hline 6 years & & & $\begin{array}{r}.089 \\
(.003)^{* * *}\end{array}$ & $\begin{array}{r}.084 \\
(.003)^{* * *}\end{array}$ & $\begin{array}{r}.115 \\
(.003)^{* * *}\end{array}$ \\
\hline 9 years & & & $\begin{array}{r}.253 \\
(.003)^{* * *}\end{array}$ & $\begin{array}{r}.251 \\
(.003)^{* * *}\end{array}$ & $\begin{array}{r}.280 \\
(.003)^{* * *}\end{array}$ \\
\hline high school & & & $\begin{array}{r}.475 \\
(.003)^{* * *}\end{array}$ & $\begin{array}{r}.470 \\
(.003)^{* * *}\end{array}$ & $\begin{array}{r}.518 \\
(.003)^{* * *}\end{array}$ \\
\hline university & & & $\begin{array}{r}1.040 \\
(.003)^{* * *}\end{array}$ & $\begin{array}{r}1.049 \\
(.003)^{* * *}\end{array}$ & $\begin{array}{r}1.098 \\
(.003)^{* * *}\end{array}$ \\
\hline \multicolumn{6}{|l|}{ Tenure (years) } \\
\hline 1 & & & & $\begin{array}{r}.028 \\
(.0005)^{* * *}\end{array}$ & $\begin{array}{r}.031 \\
(.0004)^{* * *}\end{array}$ \\
\hline 2 & & & & .055 & .060 \\
\hline
\end{tabular}




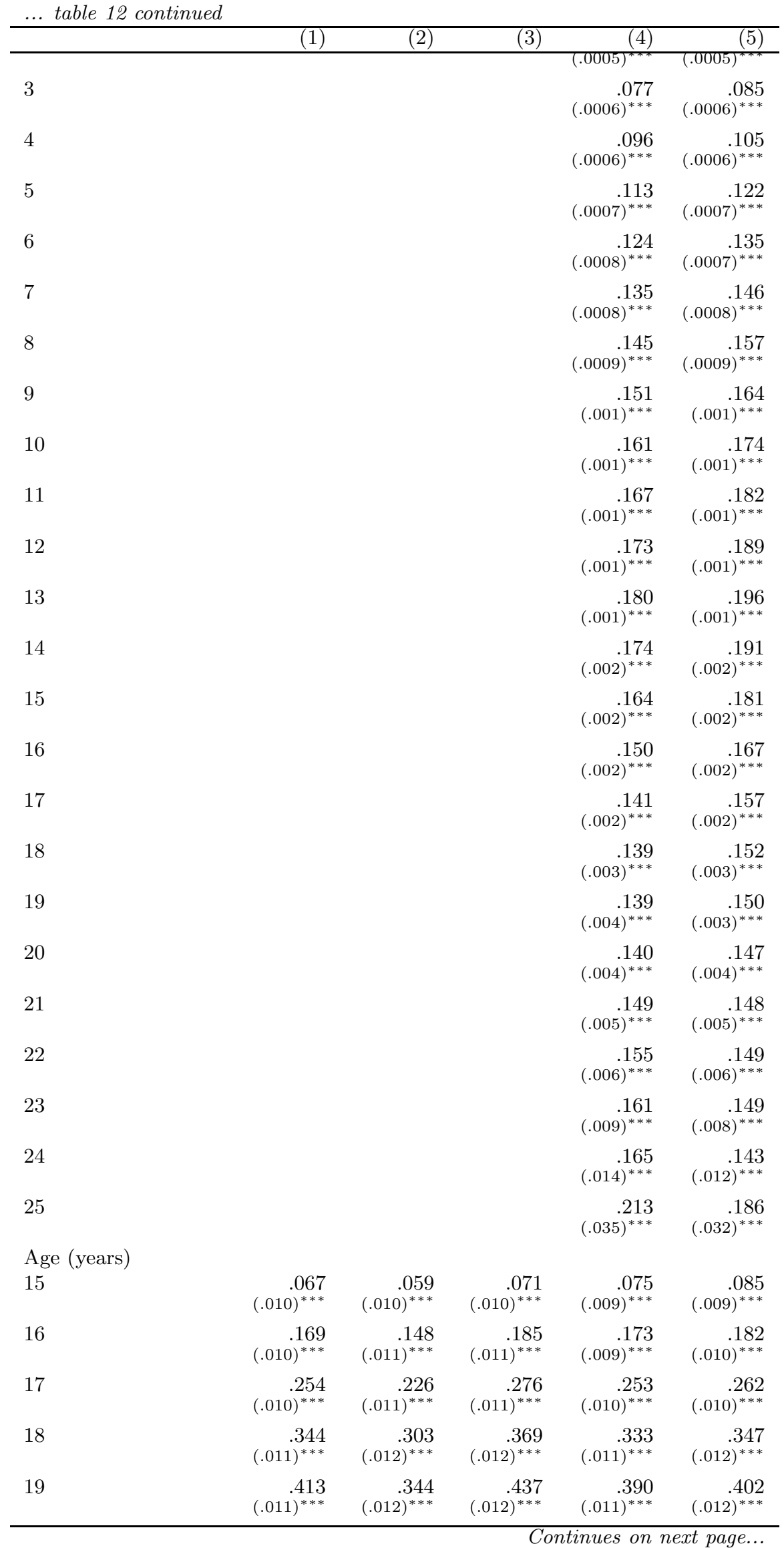




\begin{tabular}{|c|c|c|c|c|c|}
\hline & $(1)$ & $(2)$ & $(3)$ & $(4)$ & $(5)$ \\
\hline 20 & $\begin{array}{r}.463 \\
(.011)^{* * *}\end{array}$ & $\begin{array}{r}.317 \\
(.012)^{* * *}\end{array}$ & $\begin{array}{r}.496 \\
(.012)^{* * *}\end{array}$ & $\begin{array}{r}.433 \\
(.011)^{* * *}\end{array}$ & $\begin{array}{r}.447 \\
(.012)^{* * *}\end{array}$ \\
\hline 21 & $\begin{array}{r}.498 \\
(.011)^{* * *}\end{array}$ & $\begin{array}{r}.322 \\
(.012)^{* * *}\end{array}$ & $\begin{array}{r}.525 \\
(.012)^{* * *}\end{array}$ & $\begin{array}{r}.454 \\
(.011)^{* * *}\end{array}$ & $\begin{array}{r}.479 \\
(.012)^{* * *}\end{array}$ \\
\hline 22 & $\begin{array}{r}.547 \\
(.011)^{* * *}\end{array}$ & $\begin{array}{r}.354 \\
(.012)^{* * *}\end{array}$ & $\begin{array}{r}.569 \\
(.012)^{* * *}\end{array}$ & $\begin{array}{r}.494 \\
(.011)^{* * *}\end{array}$ & $\begin{array}{r}.505 \\
(.012)^{* * *}\end{array}$ \\
\hline 23 & $\begin{array}{r}.594 \\
(.011)^{* * *}\end{array}$ & $\begin{array}{r}.391 \\
(.012)^{* * *}\end{array}$ & $\begin{array}{r}.606 \\
(.012)^{* * *}\end{array}$ & $\begin{array}{r}.526 \\
(.011)^{* * *}\end{array}$ & $\begin{array}{r}.533 \\
(.012)^{* * *}\end{array}$ \\
\hline 24 & $\begin{array}{r}.640 \\
(.011)^{* * *}\end{array}$ & $\begin{array}{r}.417 \\
(.012)^{* * *}\end{array}$ & $\begin{array}{r}.641 \\
(.012)^{* * *}\end{array}$ & $\begin{array}{r}.556 \\
(.011)^{* * *}\end{array}$ & $\begin{array}{r}.559 \\
(.012)^{* * *}\end{array}$ \\
\hline 25 & $\begin{array}{r}.684 \\
(.011)^{* * *}\end{array}$ & $\begin{array}{r}.448 \\
(.012)^{* * *}\end{array}$ & $\begin{array}{r}.676 \\
(.012)^{* * *}\end{array}$ & $\begin{array}{r}.584 \\
(.011)^{* * *}\end{array}$ & $\begin{array}{r}.586 \\
(.012)^{* * *}\end{array}$ \\
\hline 26 & $\begin{array}{r}.722 \\
(.011)^{* * *}\end{array}$ & $\begin{array}{r}.476 \\
(.012)^{* * *}\end{array}$ & $\begin{array}{r}.709 \\
(.012)^{* * *}\end{array}$ & $\underset{(.011)^{* * *}}{.611}$ & $\begin{array}{r}.611 \\
(.012)^{* * *}\end{array}$ \\
\hline 27 & $\begin{array}{r}.753 \\
(.011)^{* * *}\end{array}$ & $\begin{array}{r}.500 \\
(.013)^{* * *}\end{array}$ & $\begin{array}{r}.740 \\
(.013)^{* * *}\end{array}$ & $\begin{array}{r}.636 \\
(.011)^{* * *}\end{array}$ & $\begin{array}{r}.635 \\
(.012)^{* * *}\end{array}$ \\
\hline 28 & $\begin{array}{r}.776 \\
(.011)^{* * *}\end{array}$ & $\begin{array}{r}.515 \\
(.013)^{* * *}\end{array}$ & $\begin{array}{r}.771 \\
(.013)^{* * *}\end{array}$ & $\begin{array}{r}.661 \\
(.011)^{* * *}\end{array}$ & $\begin{array}{r}.658 \\
(.012)^{* * *}\end{array}$ \\
\hline 29 & $\begin{array}{r}.794 \\
(.011)^{* * *}\end{array}$ & $\begin{array}{r}.524 \\
(.013)^{* * *}\end{array}$ & $\begin{array}{r}.802 \\
(.013)^{* * *}\end{array}$ & $\begin{array}{r}.686 \\
(.011)^{* * *}\end{array}$ & $\begin{array}{r}.682 \\
(.012)^{* * *}\end{array}$ \\
\hline 30 & $\begin{array}{r}.806 \\
(.011)^{* * *}\end{array}$ & $\begin{array}{r}.529 \\
(.013)^{* * *}\end{array}$ & $\begin{array}{r}.829 \\
(.013)^{* * *}\end{array}$ & $\begin{array}{r}.708 \\
(.011)^{* * *}\end{array}$ & $\begin{array}{r}.702 \\
(.012)^{* * *}\end{array}$ \\
\hline 31 & $\begin{array}{r}.815 \\
(.011)^{* * *}\end{array}$ & $\begin{array}{r}.530 \\
(.013)^{* * *}\end{array}$ & $\begin{array}{r}.855 \\
(.013)^{* * *}\end{array}$ & $\begin{array}{r}.729 \\
(.011)^{* * *}\end{array}$ & $\frac{.722}{(.012)^{* * *}}$ \\
\hline 32 & $\begin{array}{r}.822 \\
(.011)^{* * *}\end{array}$ & $\begin{array}{r}.529 \\
(.013)^{* * *}\end{array}$ & $\begin{array}{r}.880 \\
(.013)^{* * *}\end{array}$ & $\begin{array}{r}.749 \\
(.012)^{* * *}\end{array}$ & $\begin{array}{r}.742 \\
(.012)^{* * *}\end{array}$ \\
\hline 33 & $\begin{array}{r}.825 \\
(.011)^{* * *}\end{array}$ & $\begin{array}{r}.526 \\
(.013)^{* * *}\end{array}$ & $\begin{array}{r}.901 \\
(.013)^{* * *}\end{array}$ & $\begin{array}{r}.766 \\
(.012)^{* * *}\end{array}$ & $\begin{array}{r}.758 \\
(.012)^{* * *}\end{array}$ \\
\hline 34 & $\begin{array}{r}.825 \\
(.012)^{* * *}\end{array}$ & $\begin{array}{r}.522 \\
(.013)^{* * *}\end{array}$ & $\begin{array}{r}.922 \\
(.013)^{* * *}\end{array}$ & $\begin{array}{r}.784 \\
(.012)^{* * *}\end{array}$ & $\begin{array}{r}.776 \\
(.012)^{* * *}\end{array}$ \\
\hline 35 & $\begin{array}{r}.823 \\
(.012)^{* * *}\end{array}$ & $\begin{array}{r}.516 \\
(.013)^{* * *}\end{array}$ & $\begin{array}{r}.942 \\
(.013)^{* * *}\end{array}$ & $\begin{array}{r}.801 \\
(.012)^{* * *}\end{array}$ & $\begin{array}{r}.793 \\
(.012)^{* * *}\end{array}$ \\
\hline 36 & $\begin{array}{r}.824 \\
(.012)^{* * *}\end{array}$ & $\begin{array}{r}.510 \\
(.013)^{* * *}\end{array}$ & $\begin{array}{r}.963 \\
(.013)^{* * *}\end{array}$ & $\begin{array}{r}.820 \\
(.012)^{* * *}\end{array}$ & $\begin{array}{r}.811 \\
(.012)^{* * *}\end{array}$ \\
\hline 37 & $\begin{array}{r}.827 \\
(.012)^{* * *}\end{array}$ & $\begin{array}{r}.504 \\
(.013)^{* * *}\end{array}$ & $\begin{array}{r}.985 \\
(.013)^{* * *}\end{array}$ & $\begin{array}{r}.838 \\
(.012)^{* * *}\end{array}$ & $\begin{array}{r}.829 \\
(.012)^{* * *}\end{array}$ \\
\hline 38 & $\begin{array}{r}.828 \\
(.012)^{* * *}\end{array}$ & $\begin{array}{r}.493 \\
(.014)^{* * *}\end{array}$ & $\begin{array}{r}1.004 \\
(.013)^{* * *}\end{array}$ & $\begin{array}{r}.855 \\
(.012)^{* * *}\end{array}$ & $\begin{array}{r}.846 \\
(.012)^{* * *}\end{array}$ \\
\hline 39 & $\begin{array}{r}.835 \\
(.013)^{* * *}\end{array}$ & $\begin{array}{r}.486 \\
(.014)^{* * *}\end{array}$ & $\begin{array}{r}1.026 \\
(.013)^{* * *}\end{array}$ & $\begin{array}{r}.874 \\
(.012)^{* * *}\end{array}$ & $\begin{array}{r}.863 \\
(.013)^{* * *}\end{array}$ \\
\hline Female & & & & & $\begin{array}{r}-.220 \\
(.0007)^{* * *}\end{array}$ \\
\hline Year (dummies) & yes & yes & yes & yes & yes \\
\hline Const. & $\begin{array}{r}4.226 \\
(.039)^{* * *}\end{array}$ & $\begin{array}{r}4.613 \\
(.042)^{* * *}\end{array}$ & $\begin{array}{r}4.102 \\
(.043)^{* * *}\end{array}$ & $\begin{array}{r}4.123 \\
(.042)^{* * *}\end{array}$ & $\begin{array}{r}4.279 \\
(.044)^{* * *}\end{array}$ \\
\hline Obs. & 5161362 & 5161362 & 5161362 & 5118561 & 5118561 \\
\hline$R^{2}$ & .212 & .229 & .491 & .502 & .545 \\
\hline$F$ statistic & 23333.66 & 22073.04 & 28966.96 & 20229.63 & 20139.98 \\
\hline
\end{tabular}


Table 13: Wage regressions with exposure to high youth minimum wages interacted with tenure, first job spell observed from start

\begin{tabular}{|c|c|c|}
\hline & $(1)$ & $(2)$ \\
\hline Minimum wage $(\log )$ & $\begin{array}{r}.255 \\
(.013)^{* * * *}\end{array}$ & $\begin{array}{r}.246 \\
(.014)^{* * *}\end{array}$ \\
\hline \multicolumn{3}{|l|}{ Exposure high youth min wage } \\
\hline 1 year & $\begin{array}{r}.050 \\
(.001)^{* * *}\end{array}$ & $\begin{array}{r}.041 \\
(.001)^{* * *}\end{array}$ \\
\hline 2 years & $\begin{array}{r}.049 \\
(.002)^{* * *}\end{array}$ & $\begin{array}{r}.050 \\
(.002)^{* * *}\end{array}$ \\
\hline 3 years & $\begin{array}{r}.052 \\
(.002)^{* * *}\end{array}$ & $\begin{array}{r}.062 \\
(.002)^{* * *}\end{array}$ \\
\hline 4 years & $\begin{array}{r}.060 \\
(.002)^{* * * *}\end{array}$ & $\begin{array}{r}.073 \\
(.002)^{* * *}\end{array}$ \\
\hline 5 years & $\begin{array}{r}.070 \\
(.004)^{* * *}\end{array}$ & $\begin{array}{r}.091 \\
(.004)^{* * *}\end{array}$ \\
\hline \multicolumn{3}{|l|}{ Education } \\
\hline 4 years & $\begin{array}{r}.041 \\
(.003)^{* * *}\end{array}$ & $\begin{array}{r}.041 \\
(.003)^{* * *}\end{array}$ \\
\hline 6 years & $\begin{array}{r}.111 \\
(.003)^{* * *}\end{array}$ & $\begin{array}{r}.111 \\
(.003)^{* * *}\end{array}$ \\
\hline 9 years & $\begin{array}{r}.259 \\
(.004)^{* * *}\end{array}$ & $\begin{array}{r}.259 \\
(.004)^{* * *}\end{array}$ \\
\hline high school & $\begin{array}{r}.495 \\
(.004)^{* * *}\end{array}$ & $\begin{array}{r}.495 \\
(.004)^{* * *}\end{array}$ \\
\hline university & $\begin{array}{r}1.066 \\
(.004)^{* * * *}\end{array}$ & $\begin{array}{r}1.066 \\
(.004)^{* * *}\end{array}$ \\
\hline Female & $\begin{array}{r}-.231 \\
(.0009)^{* * *}\end{array}$ & $\begin{array}{r}-.231 \\
(.0009)^{* * *}\end{array}$ \\
\hline Year (dummies) & yes & yes \\
\hline Age (dummies) & yes & yes \\
\hline Tenure (dummies) & yes & yes \\
\hline Tenure (dummies) $*$ Exposed $(\mathrm{y} / \mathrm{n})$ & yes & no \\
\hline Tenure (dummies) $*$ Exposure (dummies) & no & yes \\
\hline Const. & $\begin{array}{r}3.926 \\
(.068)^{* * *}\end{array}$ & $\begin{array}{r}3.955 \\
(.069)^{* * *}\end{array}$ \\
\hline Obs. & 2814379 & 2814379 \\
\hline$R^{2}$ & .529 & .529 \\
\hline$F$ statistic & 9380.391 & 5125.709 \\
\hline
\end{tabular}

Note: The estimated coefficients on the interaction terms are plotted in figure 8 . 